\title{
Additional Fossil Theropithecus From Hopefield, South Africa: A Comparison With Other African Sites and a Reevaluation of its Taxonomic Status
}

PAUL C. DECHOW AND RONALD SINGER

Department of Anatomy and Cell Biology, The University of Michigan, Ann Arbor, Michigan 48109 (P.C.D.) and Department of Anatomy, University of Chicago, Illinois 60637 (R.S.)

\author{
KEY WORDS Fossil Theropithecus; Taxonomy; Hopefield, South \\ Africa; Cranial and dental variation
}

\begin{abstract}
Additional fossil Theropithecus remains, recovered from mid to late Pleistocene deposits near Hopefield, South Africa, include portions of the jaws of at least five individuals. Extensive comparisons with fossil Theropithecus from other African sites, including Makapan, Swartkrans, Kanjera, Olorgesailie, and Olduvai, reveal few morphological differences, especially when variation in modern gelada baboons (Theropithecus gelada) and savannah baboons (Papio) is considered. The most pronounced differences between fossil forms are overall size and relative $P_{3}$ length. However, these traits do not separate the fossil forms either chronologically or geographically. Other traits, such as depth of the fossa of the mandibular corpus, slope of the upper symphyseal shelf, and variation in the depth of the mandibular corpus, do not distinguish alleged primitive forms (Makapan and lower beds at Olduvai) from remains found at Hopefield, Swartkrans, Kanjera, Olorgesailie, Olduvai Bed IV, or the lower Ndutu Beds. Other traits, such as canine crown height and incisor size, are poorly documented for fossil Theropithecus. Thus, the available evidence suggests that Theropithecus darti and its successional species, $T$. oswaldi, can best be considered as a single fossil species, $T$. oswaldi, of which the remains from Hopefield are a late representative. Furthermore, lack of morphological differences dictates that Hopefield Theropithecus not be considered a distinct subspecies. Variation within the Hopefield sample shows that only one taxa is found at this site. Hypothesized physical and climatic conditions at Hopefield during the Pleistocene suggest that $T$. oswaldi lived near vleis or fresh water lagoons. Comparisons with modern $T$. gelada suggest a graminivorous diet for the fossil form.
\end{abstract}

Fossil remains of Theropithecus have been found at a variety of Pleistocene sites throughout northern, eastern, and southern Africa (Freedman, 1957; Jolly, 1972; Szalay and Delson, 1979), and several taxonomic schemes have been proposed to account for their morphological diversity. The most general scheme suggests the evolution of several cranial features throughout the Pleistocene, including 1) reduction of the size of the fossa of the mandibular corpus ${ }^{1} ; 2$ ) reduction of male $\mathrm{P}_{3}$ length and canine height; 3 ) flatten-

Received November 1, 1982; revised December 7, 1983; accepted December 22, 1983.
IThe term "fossa of the mandibular corpus" denotes a fossa located on cercopithecoid mandibles on the superficial aspect of the corpus inferior to $P_{3}$ and $P_{4}$. This structure is usually referred to as the mandibular fossa (see Freedman, 1957 for example). However, the fossa mandibularis is defined in the Nomina Anatomica as an entity of the pars squamosa of the os temporale, indicating the articular surface for the condyle of the mandible in the temporomandibular joint. In cercopithecoid monkeys, the structure of the bony parts of the temporomandibular joint differs from that in humans. The mandibular fossa is not deeply excavated with only a thin wall of bone separating it from the middle cranial fossa. Rather, the mandibular fossa is more of a platform that cannot be easily distinguished from what would be the articular eminence in humans. The portion of the temporal bone supporting the fossa is thick. In any case, for consistency and correctness in the anatomical literature, it is suggested that the structure in cercopithecoid primates that is referred to by Freedman (1957) and others as the mandibular fossa should hereafter be referred to as the fossa of the mandibular corpus, and mandibular fossa be reserved to denote the recessed portion of the temporal articular surface of the jaw joint. 
ing of the upper symphyseal shelf; 4) development of equal depth of the posterior and anterior mandibular corpus contrasting with the proposed primitive condition where the mandibular corpus deepens anteriorly, 5) greater specialization of cheek teeth; and 6) reduction of incisor size (Jolly, 1972; Szalay and Delson, 1979).

Fossil Theropithecus from the Middle to Upper Pleistocene site 'Elandsfontein" near Hopefield, South Africa, has been thought to represent an advanced form (Freedman, 1957; Jolly, 1972; Szalay and Delson, 1979). Additional undescribed remains aid in reassessing Hopefield Theropithecus in particular and, in general, the morphology and evolution of fossil members of the genus as a whole. The goals of this paper are: 1) to describe additional fossil Theropithecus from Hopefield, South Africa; 2) to make comparisons with described fossil Theropithecus; 3) to compare modern baboons to assess variability in the fossils; 4) to reevaluate the taxonomic position of Hopefield Theropithecus; and 5) to speculate on its natural history.

The extensive fossiliferous site on the farm "Elandsfontein" near Hopefield in the southwestern part of the Cape Provence has yielded, mainly by surface collecting, several thousand fossils of approximately fifty species of mammals including Homo (see Drennan, 1954; Drennan and Singer, 1955; Ewer and Singer, 1956; Hendey, 1974; Hooijer and Singer, 1960, 1961; Keen and Singer, 1956; Singer, 1954, 1957; Singer and Boné, 1960; Singer annd Inskeep, 1961; Singer and Keen, 1955). Preliminary archeological data have been recorded (Singer and Crawford, 1957; Singer and Wymer, 1968) but an extensive monograph detailing the description of the site, its stratigraphy, the various archeological excavations, and an analysis of the fauna is in preparation. The fossil baboon remains are of particular interest as they represent the southernmost extent of the range of this genus.

\section{MATERIALS AND METHODS}

Singer's (1962) descriptions of Hopefield Theropithecus include a partially reconstructed calvaria and other possibly associated skull fragments, an incomplete right mandibular corpus, several isolated teeth, and a proximal radius. Additional remains discussed in the present study are two fragmentary mandibles (16647 and 16648) (Figs.
1,2 ), an incomplete left mandibular corpus (16649) (Fig. 3), a right $\mathrm{P}_{3}(16650 \mathrm{C})$, and a series of gnathic fragments probably derived from a single individual, which include a left $\mathrm{I}^{2}(16680)$, a portion of a left mandibular corpus (16680A) (Fig. 3), a right $\mathrm{M}_{3}$ with a piece of mandible attached (16680B) (Fig. 3), a right $\mathrm{M}_{2}(16680 \mathrm{C})$, a right $\mathrm{P}_{4}(16680 \mathrm{D})$, and a canine root fragment (possibly upper left) (16680F). These fossils are currently in the laboratory of one of us (R.S.) in the Department of Anatomy at the University of Chicago, but will soon be returned to the South African Museum, Cape Town, where the collection is permanently housed.

One specimen (16650C) was recovered by J. and H.J. Deacon on January 21, 1964 on the surface near a trench excavation in a ferruginous plain about $730 \mathrm{~m}$ north of the site of recovery of the specimens described by Singer (1962). Six other fragments (16650A,B, $\mathrm{D}, \mathrm{E}, \mathrm{F}, \mathrm{G})$ found there are now considered not to represent Theropithecus. The other specimens described here were recovered on the surface in January, 1964 by one of us (RS) and some students at two separate areas, about $275 \mathrm{~m}$ apart and about $1.8 \mathrm{~km}$ north of Main Site (see Fig. 1 in Singer, 1962). The fossil horizons are discussed by Singer and Wymer (1968) and comments on the dispersal of the fossils are given by Singer and Heltne (1966) and Inskeep and Hendey (1966).

Cranial features were measured on skulls ( $\mathrm{n}=696$ ) of extant wild baboons (genera Mandrillus, Papio, and Theropithecus, to estimate variability. These features and their significance are described at appropriate locations throughout this paper. The baboon crania are located in museums throughout North America and Europe. (For a more complete description of specimens and measurement techniques, see Dechow, 1980.) Statistics on modern baboon measurements are not described fully in this paper if data for one or two modern groups is sufficient for analyzing variation.

\section{DESCRIPTION}

Measurements similar to those discussed by Freedman (1957) were taken on all specimens wherever possible (see Table 1 for mandibular dental measurements and subsequent text for other measurements).

Specimen 1667 (Fig. 1), a fragmentary juvenile mandible, is reconstructed from two hemimandibles (16647A and 16647B) broken 

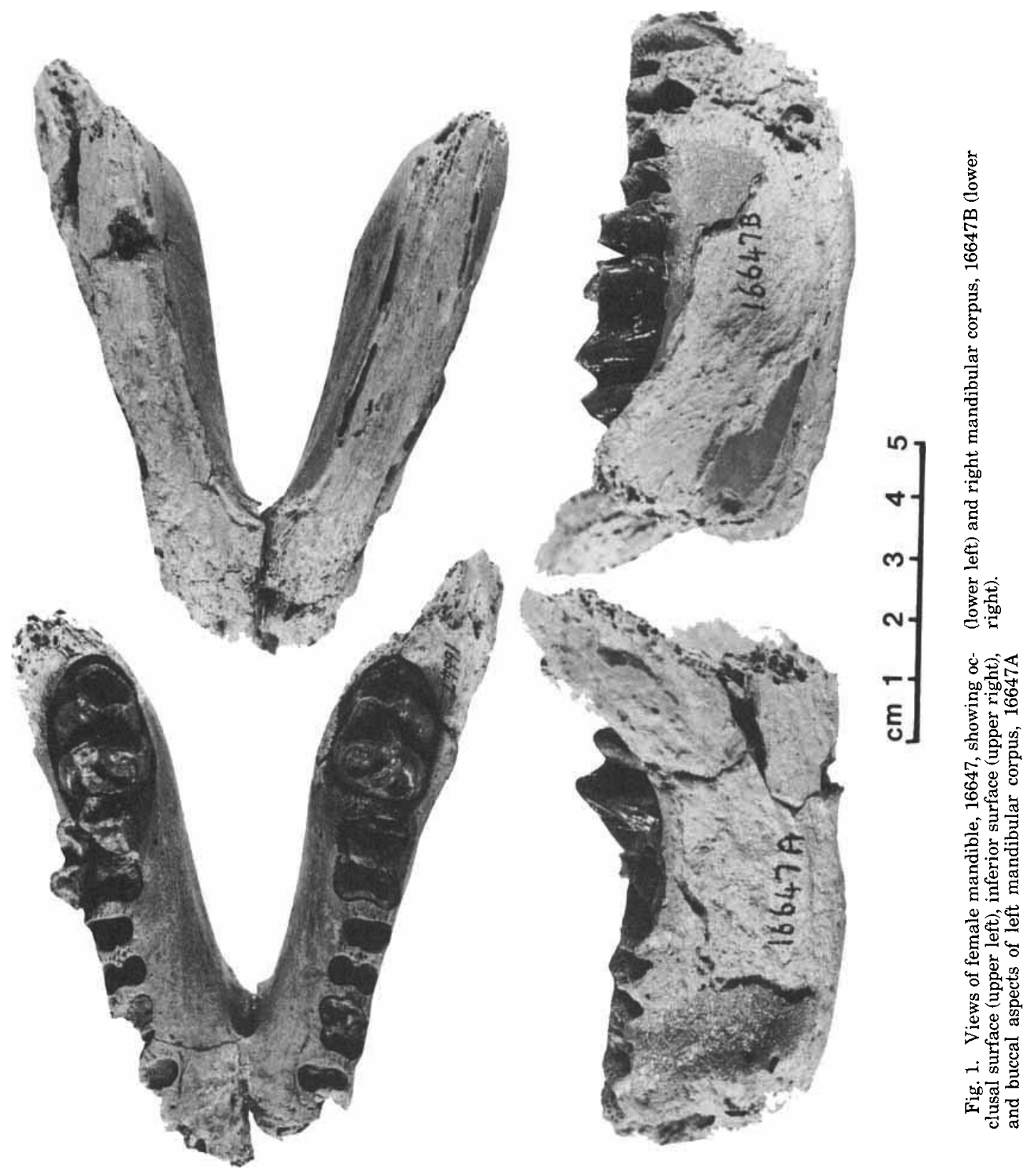

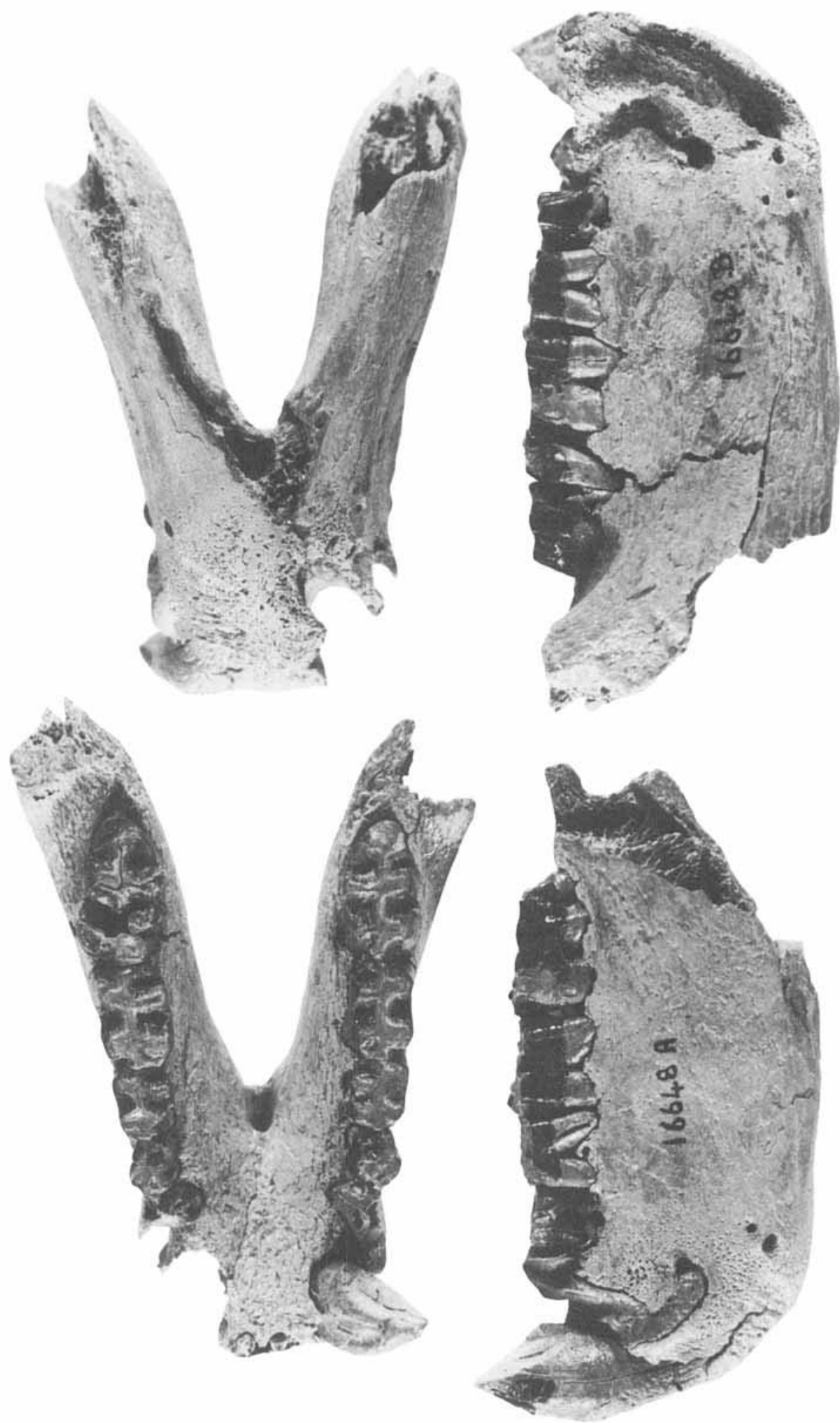

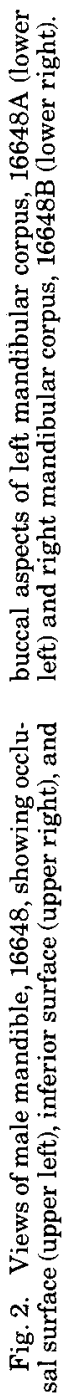


at the symphysis. The $\mathrm{P}_{3}$ root and root socket morphology indicate that this specimen is from a male.

The eroded and broken external symphysis reveals the roots of the canines. A small piece of the alveolus that surrounded the incisor roots remains with the tip of the right $I_{1}$ root lodged therein. The internal symphysis is complete superior to the mandibular torus. Inferior to the torus, the bone is eroded obliterating much of the area of the suprahyoid muscle attachment and the canal for the inferior lingual artery. The superior symphyseal shelf extends distally to the level of the mesial roots of $\mathrm{P}_{4}$ while the inferior symphyseal shelf extends distally to the mesial roots of $\mathrm{M}_{1}$. The superior shelf is poorly developed as expected in a young specimen.

Three mental foramena are found inferior to the premolars bilaterally, while the left hemimandible (16647A) has a portion (see Fig. 1) of ascending ramus present. The surface cortical bone is eroded away from much of the buccal surface but is intact on the lingual surface. The fossa of the mandibular corpus has only minimal development. Due to the erosion of cortical bone, width and height measurements can only be approximated as follows: maximum width at the level of the mesial margin of $\mathrm{M}_{3}$ (right)-21.4 $\mathrm{mm}$, (left)--21.7 mm; height at the level of the mesial margin of $\mathrm{M}_{3}$ (right) $-32.0 \mathrm{~mm}$, (left)-31.4 mm; maximum width at the level of the mesial margin of $\mathrm{M}_{1}$ (right) $-17.3 \mathrm{~mm}$, (side)-16.4 $\mathrm{mm}$; maximum height at the level of the mesial margin of $M_{1}$ (right)-37.6 $\mathrm{mm}$, (left) $-38.4 \mathrm{~mm}$.

The dentition is fragmentary. The only complete teeth are the left and right $\mathrm{M}_{3} \mathrm{~S}$, which are not fully erupted and exhibit wear only on their mesial cusps. Their morphology is similar to that described by Freedman (1957, p. 210) for lower molars from Swartkrans. The right $M_{2}$ has present the buccal wall of the crown and roots. Portions of the roots and the distal part of the mesial wall are also present for the left $\mathrm{M}_{2}, \mathrm{M}_{1}, \mathrm{P}_{4}, \mathrm{P}_{3}$, and canine and the right $\mathrm{M}_{1}, \mathrm{P}_{4}, \mathrm{P}_{3}$, and canine. The length of the cheek tooth row from the distal margin of $\mathrm{M}_{3}$ to the mesial margin of $\mathrm{P}_{4}$ are $67 \mathrm{~mm}$ (right side) and 69 $\mathrm{mm}$ (left side).

Specimen 16648 (Fig. 2) is fragmentary adult mandible found in two parts $(A, B)$ and rejoined at the fracture line through the right canine socket. The specimen is male as is evident from $\mathrm{P}_{3}$ and canine morphology.

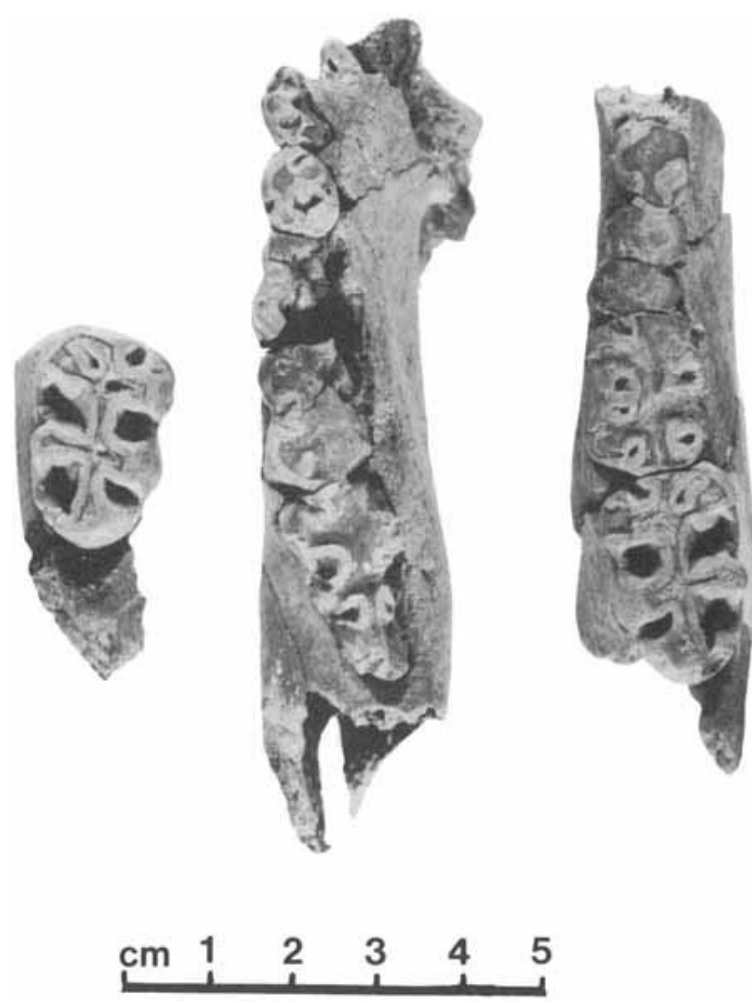

Fig. 3. Occlusal views of right $\mathrm{M}_{3}, 16680 \mathrm{~B}$ (left), and left hemimandibles, 16649 and $16680 \mathrm{~A}$ (center and right).

The external symphysis is intact anteriorly but is broken away inferior to the proximal inferior symphyseal shelf. The right canine and the cortical bone anterolateral to its root are missing. The incisors are absent although the roots remain. The alveolus that bordered the medial face of the right $\mathrm{I}_{2}$ is discernable in the empty root socket of the right canine; the alveolus that bordered the lateral root face is missing. An estimate of the incisor root width at the alveolar junction is $18 \mathrm{~mm}$. The superior symphyseal shelf is long, with a gradual slope extending posteriorly to the distal cusps of $\mathrm{P}_{4}$. The inferior symphyseal shelf extends to the distal cusps of $\mathrm{M}_{1}$. The pit between the inferior and superior symphyseal shelves contains three foramina; two are probably secondarily enlarged due to postmortem deterioration.

The cortical bone is largely complete on the buccal and lingual surfaces of the mandibu- 
lar corpora. On the left side, the cortical bone is deteriorated over the roots of the canine and $P_{3}$. The remaining bone is cracked and pitted. On the right side, the bone overlying the root sockets of the canine and $\mathrm{P}_{3}$ is missing. Multiple mental foramina (2-left; 3right) are present. A large pit, which is probably the result of postmortem deterioration rather than chronic abscess formation, lies near the mesial root tip of the left $\mathrm{P}_{3}$. Little development of the fossa of the mandibular corpus is apparent. Both hemimandibles are broken posterior to $\mathrm{M}_{3}$ although small por. tions of the ascending rami are present on both sides. A groove passes obliquely from within outward, forward, and downward from the buccal alveolar margin behind $\mathrm{M}_{3}$ to near the mesial cusp of $\mathrm{M}_{3}$. Singer (1962, p. 49) concludes from studies of modern savannah baboon anatomy that this "groove was probably occupied partly by a thickened buccinator muscle but mainly by a pad of fat acting as a bursa between temporalis and buccinator." On the left side, the buccal wall of bone is broken away posteriorly revealing a mandibular canal sweeping downward into the corpus. Height and width measurements of the mandible are as follows: maximum width at the level of the mesial margin of $\mathrm{M}_{3}$ (right) $-22.0 \mathrm{~mm}$, (left) $-21.8 \mathrm{~mm}$; maximum width at the level of the mesial margin of $\mathrm{M}_{1}$ (right) $-20.3 \mathrm{~mm}$, (left) $-19.3 \mathrm{~mm}$; height at the level of the mesial margin of $\mathrm{M}_{3}$ (right)$44.3 \mathrm{~mm}$, (left) $-43.5 \mathrm{~mm}$; height at the level of the mesial margin of $\mathrm{M}_{1}$ (right)- $43.1 \mathrm{~mm}$, (left)-43.3 mm.

Most of the dentition are damaged and some teeth are missing. The left corpus has the canine through $\mathrm{M}_{3}$ present. On $\mathrm{M}_{3}$, the enamel is missing distally and the tooth is broken on the buccal aspect of the protoconid and the mesial aspect of the metaconid. On $\mathrm{M}_{2}$, the enamel is missing lingually while on $\mathrm{M}_{1}$, it is missing mesially. $\mathrm{P}_{4}$ has some breakage on its lingual aspect. $\mathrm{P}_{3}$ is extensively damaged with only the distal cusp intact; the honing surface is broken away. The canine is in good condition although enamel is missing from most of its surface. The right corpus has $\mathrm{P}_{3}$ through $\mathrm{M}_{3}$ present. $\mathrm{M}_{3}$ has some breakage on the protoconid and metaconid. On $\mathrm{M}_{2}$, enamel is missing on the buccal face of the hypoconid while on $\mathrm{M}_{1}$, the lingual face of the metaconid is broken. $\mathrm{P}_{4}$ is damaged on its lingual surface. $P_{3}$ has only its distal root present. The root sockets of the right mesial root of $\mathrm{P}_{3}$ and the right canine

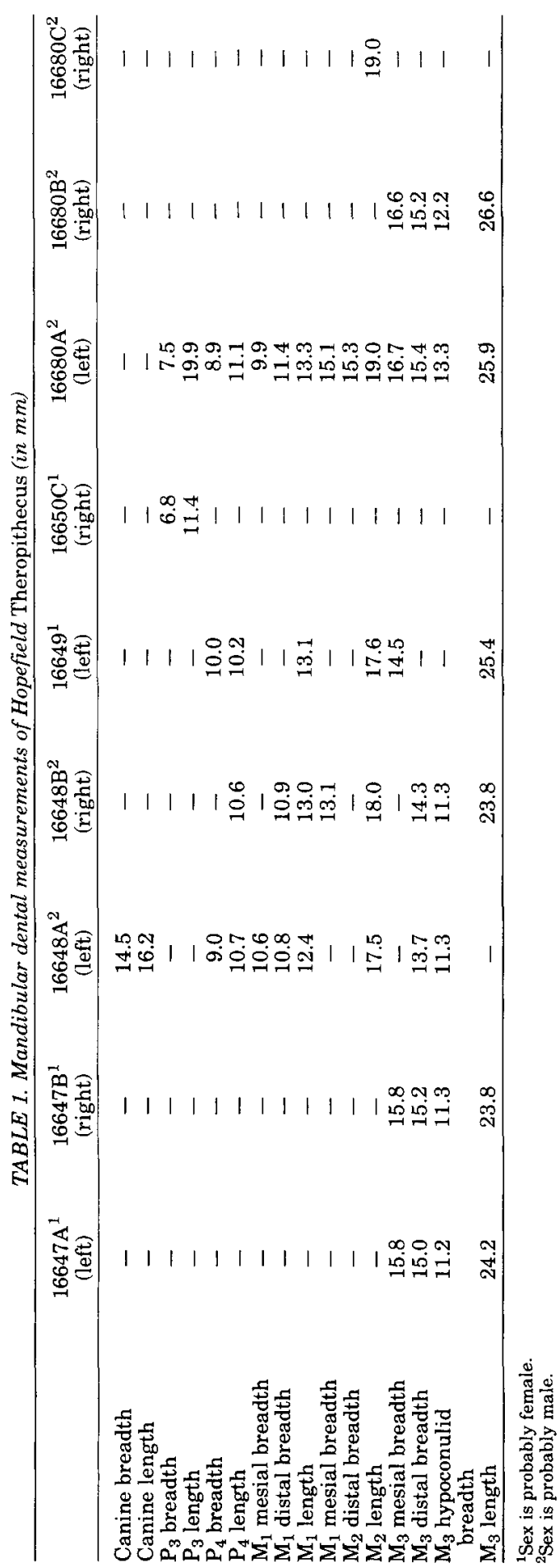


are exposed buccally. The incisors are missing except for remnants of the roots of the $I_{1}$ s. The wear on the cheek teeth reveals dentine connecting all cusps on each tooth.

The morphology of the dentition is similar to that described by Freedman (1957) for Theropithecus from Swartkrans and Makapan. The length of the cheek tooth row from the distal margin of $\mathrm{M}_{3}$ to the mesial margin of $\mathrm{P}_{4}$ is $68.4 \mathrm{~mm}$ (right) and $66.2 \mathrm{~mm}$ (left).

Specimen 16649 (Fig. 3) is an adult left hemimandible reconstructed from seven fragments. $P_{3}$ morphology indicates this specimen is female.

Anteriorly, the corpus is irregularly fractured at the symphysis. However, the mandibular torus and the genial region can be partially discerned in cross-section. The symphysis opens into the root chamber of the canine as much of its internal structure is not present. The incisors and the incisal alveolus are broken away. The superior symphyseal shelf extends distally to the distal border of $\mathrm{P}_{4}$ and slopes downward at a steeper angle relative to the occlusal plane than in specimen 16648.

Posteriorly, the mandibular corpus is truncated posterior to $\mathrm{M}_{3}$ although some ascending ramus is present. Two mental foramina are present on the buccal surface of the corpus inferior to the $\mathrm{P}_{4}$ roots. The cortical bone surface is intact over most of the surface of the specimen. The alveolar bone that covers the buccal roots of $P_{3}$ through $\mathrm{M}_{2}$ is missing. The damage is much less lingually. Height and width measurements of the mandible are as follows: maximum width at the level of the mesial margin of $\mathrm{M}_{3}-22.4 \mathrm{~mm}$; height at the level of the mesial margin of $\mathrm{M}_{3}-35.0$ $\mathrm{mm}$; height at the level of the mesial margin of $\mathrm{M}_{1}-35.3 \mathrm{~mm}$. The breadth measurement at the mesial margin of $P_{4}$ was estimated at $18 \mathrm{~mm}$.

The dentition consists of $\mathrm{M}_{3}$ through the canine. $\mathrm{M}_{3}$ has enamel broken away on all aspects but is most damaged lingually. $\mathrm{M}_{2}$ also evinces some damage lingually. $\mathrm{M}_{1}$ has extensive lingual damage; the metaconid and the entoconid are not present. $\mathrm{P}_{4}$ and the honing blade of $\mathrm{P}_{3}$ are missing enamel mesiolingually. The canine is fractured below the level of the crown. The teeth are more worn than in specimen 16648 so that the occlusal surfaces form a dentine pool surrounded by a ridge of enamel.

Specimen $16650 \mathrm{C}$ is the crown of a right $P_{3}$. The sex is female.
Specimens 16680, 16680A (Fig. 3), 16680B (Fig. 3), $16680 \mathrm{C}, 16680 \mathrm{D}$, and $16680 \mathrm{~F}$ are probably from a single individual as is indicated by the similar size and analogous amounts of wear of contralateral cheek teeth. Mandibular bone in these specimens is not extensive. The long sloping sectorial cusp on $\mathrm{P}_{3}$ of $16680 \mathrm{~A}$ indicates a male individual.

Specimen 16680 is a left $\mathrm{I}^{2}$. The root is embedded in a piece of alveolar bone and, except for a small portion on the lateral aspect of the root, cannot be seen. The tooth is considerably worn and its long axis leans mesially relative to the occlusal surface of the crown. The wear is reminiscent of older specimens of Papio or Mandrillus. Freedman (1957, p. 208) reports $\mathrm{I}^{2} \mathrm{~s}$ on a female cranium from Swartkrans that, like the Hopefield specimens, are small and lean "mesially as in Papio ursinus." By contrast, modern Theropithecus has small closely packed incisors that do not wear to this extent and in which, the $\mathrm{I}^{2} \mathrm{~s}$ do not lean mesially (Dechow, unpublished data).

Specimen $16680 \mathrm{~A}$ consists of the alveolar region of a left corpus with the left $\mathrm{M}_{3}$ through $\mathrm{P}_{4}$ intact. The corpus is fractured directly posterior to $\mathrm{M}_{3}$. Anteriorly, a space for the distal root of $P_{3}$ is evident. The left $P_{3}$ (also labeled 16680A) is detached from the mandible. On the right side, the alveolar bone is present only on the lingual aspect of $\mathrm{M}_{3}$ (16680B).

The dentition is well-preserved, especially on the left side, but is considerably worn with wide dentine exposure on the occlusal surfaces. The sectorial surface of the left $P_{3}$ is destroyed mesially. The right $\mathrm{M}_{2}(16680 \mathrm{C})$ has most of its lingual aspect missing. The anterior or posterior breadth of this tooth could not be measured. The right $\mathrm{P}_{4}$ is sufficiently damaged that neither length nor breadth could be measured. Specimen $16680 \mathrm{~F}$ is the root of a male baboon canine, possibly a left upper canine, that is probably part of the same individual as the other fragments because of its superficial resemblance, sex, and proximity to the other specimens at the time of discovery.

\section{RESULTS AND DISCUSSION \\ Morphological Comparisons with Remains from other Sites}

Fossil Theropithecus has been found throughout Africa (Fig. 4) at Makapan (Freedman, 1957, 1960, 1976; Maier, 1970, 1972), Swartkrans (Freedman, 1957; Freed- 


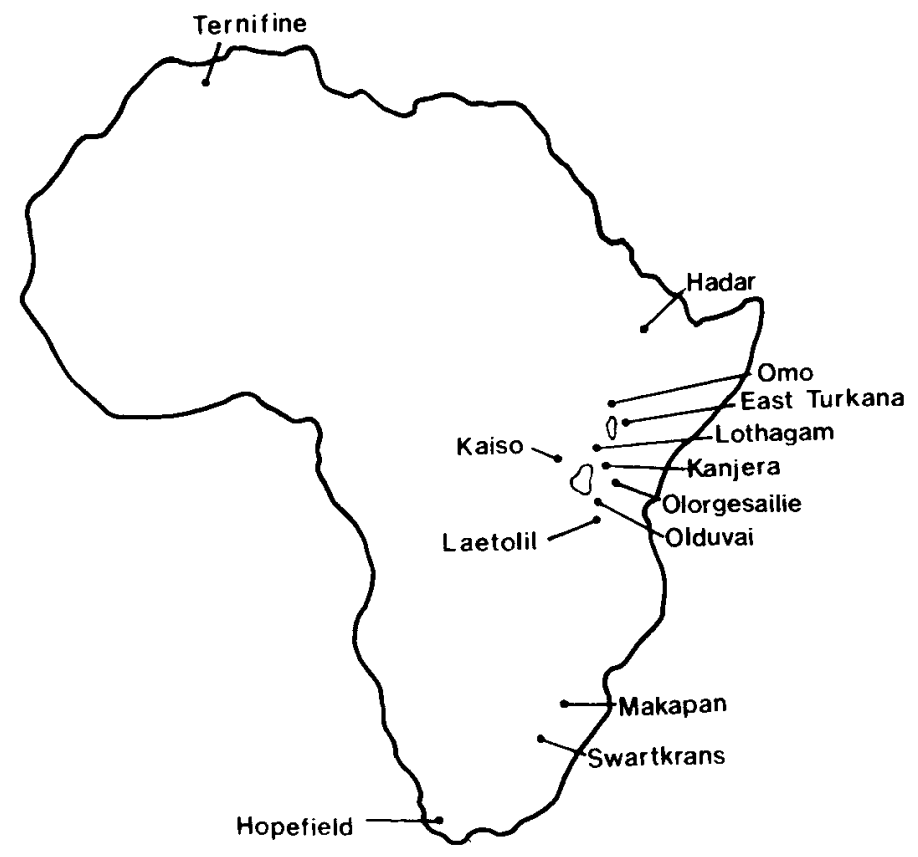

Fig. 4. Distribution of African Plio-Pleistocene sites where fossil Theropithecus have been found. Hopefield represents the southernmost extent of the range.

man and Brain, 1977), and Hopefield (Singer, 1962) in southern Africa; Kanjera (Andrews, 1916; Hopwood, 1936; Jolly, 1972; Leakey, 1943), Omo Valley (Arambourg, 1947; Butzer, 1971; Eck, 1976, 1977), Lake Turkana (Leakey, 1970, 1976), Lothagam Hill (Patterson et al., 1970), Olorgesailie (Jolly, 1972; Leakey and Leakey, 1973); Olduvai (Hopwood, 1934; Jolly, 1972; Leakey, 1965; Leakey and Leakey, 1973; Leakey and Whitworth, 1958), Kaiso (Hopwood, 1939), Hadar (Szalay and Delson, 1979; Taieb et al., 1976), Melka Kunturé (Geraads, 1979), Chesowanja (Carney et al., 1971), and Bodo D'ar (Kalb et al., 1980, and other Awash Valley localities (Kalb et al., 1982a,b) in eastern Africa; and Ternifine, Algeria (Arambourg, 1962; Delson, 1974; Szalay and Delson, 1979), Ain Jourdel, Algeria (Delson, 1975; Simons and Delson, 1978; Szalay and Delson, 1979) and Thomas Quarry, Morocco (Geraads, 1980) in northern Africa. The dating of the material from these localities ranges throughout the Plio-Pleistocene and is reviewed by Jolly (1972), Maier (1972), and Szalay and Delson (1979).

Morphological and/or metrical descriptions of the fossils are available from many of the sites listed above. Eck (1976) states that 1343 specimens have been recovered from the Usno and Shungura Formations in the Omo Valley of which two dozen are relatively complete crania and mandibles (Eck, 1977). Several photographs and a brief description show that several of these specimens differ from other Theropithecus in having "larger, flaring zygomtic bones" and "sharp well defined maxillary ridges and deep maxillary fossae." Eck assigns the name Theropithecus brumpti to these specimens after the specific name given to some dental fragments from the Omo by Arambourg (1947). As comparable zygomatic or maxillary fragments have not been found at Hopefield, it is not possible to compare the features of $T$. brumpti with the Hopefield specimens. Eck states that "the mandibles ... are not as distinct." However, T. brumpti usually have well defined fossae of the mandibular corpora while the Hopefield specimens have only minimally developed fossae. The several jaw and dental fragments that are described from the Omo by Arambroug (1947) are not distinguishable from the type Theropithecus oswaldi fragments found at Kanjera (Jolly, 1972). Eck and Howell (1982) show that one of Arambourg's specimens differs from the others and 
thus is designated as the lectotype of $T$. brumpti. The length and width of the molar teeth from the Omo (Arambourg, 1947) fall toward the lower end of the range of similar measurements of the Hopefield dentition.

Leakey (1976) reports that more than 300 cranial and postcranial fragments of Theropithecus were found in the Koobi Fora and Kubi Algi Formations at East Turkana. Fossil Theropithecus sp. from Hadar are mentioned in faunal lists by Taieb et al. (1976), and more extensive descriptions are in preparation (Delson, personal communication). A variety of Theropithecus has been recovered from localities in the Middle Awash, Afar, Ethiopia (Kalb et al., 1980, 1982a,b). Specimens are a variety of cranial and postcranial material and include several well preserved crania.

Several sites from East and North Africa reveal minimal Theropithecus material. In East Africa, a single lower molar from Lothagam Hill (Lothagam 3) (Patterson et al., 1970) is described by Simons and Delson (1978, p. 106) as having "a morphology rather typical of early Theropithecus." From Kaiso, a maxillary fragment with well worn $\mathrm{M}_{2} \mathrm{~s}$ and $\mathrm{M}_{3} \mathrm{~S}$ is known (Hopwood, 1939). A small number of gnathic fragments from Laetolil are attributed to Theropithecus by Dietrich (1942) and Leakey and Whitworth (1958) although Freedman $(1957,1960)$ and Jolly (1972) suggest that they are probably Papio or Parapapio since the ranges of tooth measurements are less than any known fossil Theropithecus. More recently, Leakey et al. (1976) mention that fossil Theropithecus, which are found in deposits in the southern Serengeti Plains, are not from the Laetolil Beds (Szalay and Delson, 1979, pp. 346-7).

Two sites in Algeria with scanty fossil Theropithecus are Ain Jourdel and Ternifine. A lower molar from Ain Jourdel, described as Cynocephalus atlanticus by Thomas (1884) is assigned to Theropithecus by Delson (1975), Simons and Delson (1978), and Szalay and Delson (1979). Remains from Ternifine have been mentioned (Arambourg, 1962; Delson, 1974; Szalay and Delson, 1979) but not described.

An incomplete mandible, and several isolated teeth of Theropithecus have been recovered from Thomas quarries near Casablanca, Morocco (Geraads, 1980). Measurements (Table 2) and brief descriptions of these remains suggest similarity in size and morphology with the Hopefield fossils.

More extensive descriptions and measurements are available for fossil Theropithecus from the remaining sites in South and East Africa. Table 2 presents statistics for the mandibular dental measurements. Data are derived from multiple sources, as follows: Hopefield-Singer (1962 and this study); Makapan-Freedman (1957, 1960); Maier (1970, 1972); Swartkrans-Freedman (1957); Kanjera-Jolly (1972); Olorgesailie and OlduvaiJolly (1972); Leakey and Leakey, (1973). Figure 5 plots ranges of combined male and female tooth length and mesial breadth. Figure 6 plots tooth length means for each sex. The sexing of the fossils was based on differences in the upper canines and $\mathrm{P}_{3} \mathrm{~S}$ wherever possible. However, some sexing of Makapan and Swartkrans remains by Freedman (1957, 1960 ) is based on size alone.

Makapan: The 27Theropithecus fossils from Makapan consist predominantly of mandibular fragments (Freedman, 1976) but also include one nearly complete female skull (Maier, 1970, 1972).

Freedman (1957, 1960), Jolly (1972), Maier (1970), Simons and Delson (1978), and Szalay and Delson (1979) propose primitive morphological features that distinguish Makapan Theropithecus from fossils found at other localities, particularly those from East Africa. Those features that are relevant to the morphology of the Hopefield specimens include 1) the presence of fossae of the mandibular corpora; 2) molar structure that is closer to the typical cercopithecine pattern than that found on fossils from Kanjera, 3) relatively long $\mathrm{P}_{3} \mathrm{~s} ; 4$ ) high-crowned male upper canines; 5) a more abruptly downward-sloping superior symphyseal shelf; 6) greater mandibular corpus depth relative to length; 7) mandibular corpora that deepen in their vertical dimensons mesially; and 8) relatively broad incisors (Dechow, 1981). Each of these features is discussed here in turn.

Well-developed fossae of the mandibular corpora are not present on any specimen from Hopefield. Conversely, one adult male specimen (M.626) from Makapan has "very large and deep" fossae while those of another adult male (M.201) are "almost totally absent" (Freedman, 1957, p. 204). Freedman (1960, p. 43) refers to a specimen (M.621) as having "very deep" fossae. This specimen is probably the same as that discussed in his 1957 study as M.626, as nowhere in his descriptions of the Makapan fossils (Freedman, 1957, 1960 ) is a specimen described under the catalog number M.621. Maier (1970) notes that several Makapan adult specimens, including M.201, M.621 (M.626?), and M.3074, have "a kind of" fossa of the mandibular corpus but 


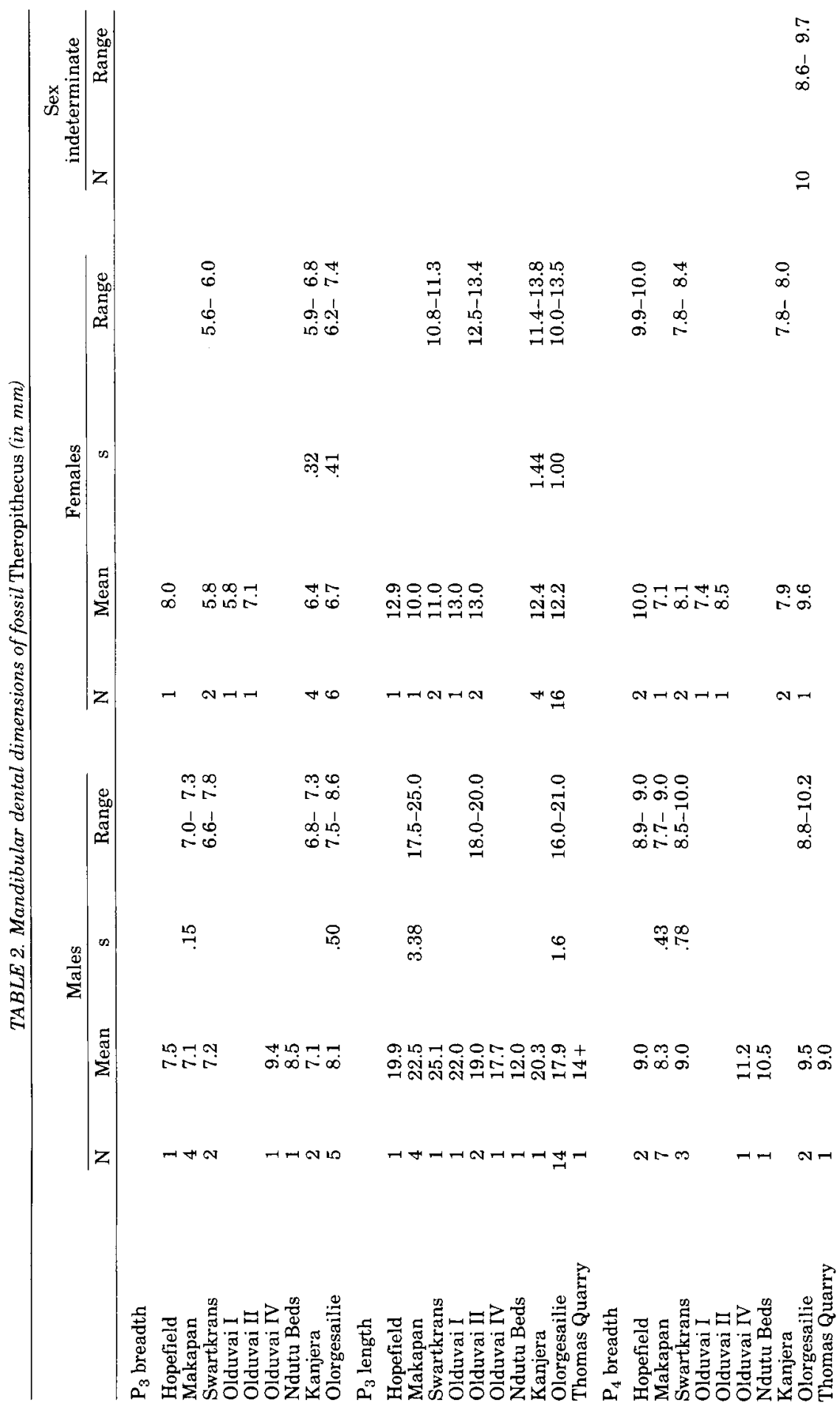




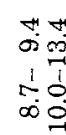

œ

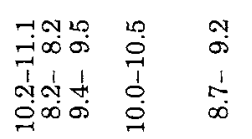

$\begin{array}{cc} & 0 \\ & \infty \\ \infty & \vdots \\ \infty & \infty \\ \infty & \infty\end{array}$

$7 \quad 20$

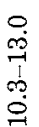

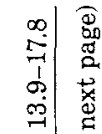

- 19

N

ธั

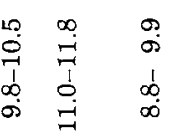

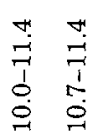

$\sigma$
$\sigma$
$\vdots$
$\dot{\sigma}$

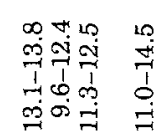

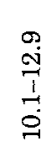

只 药

$\stackrel{9}{1}$

$\stackrel{20}{\sharp ! ~}$

\%

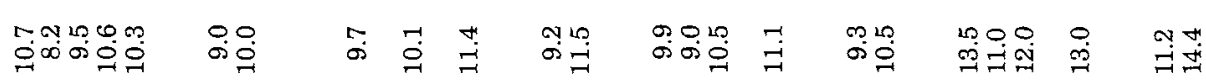

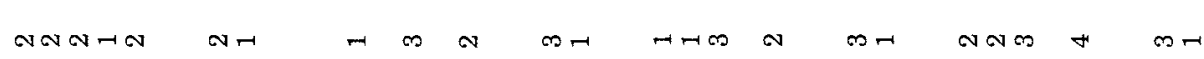

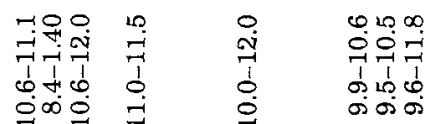

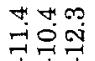
o.

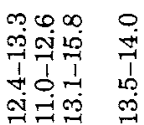
ำ 우

๙ุ๊

남ำ

\begin{tabular}{|c|c|c|c|c|c|c|}
\hline 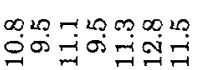 & 잌 & :엉 & $\stackrel{\circ}{=\infty}$ & 유마 & 얼 & 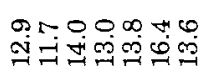 \\
\hline$-\infty \sim N$ & 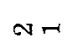 & NS & & in & & $\infty$ \\
\hline
\end{tabular}

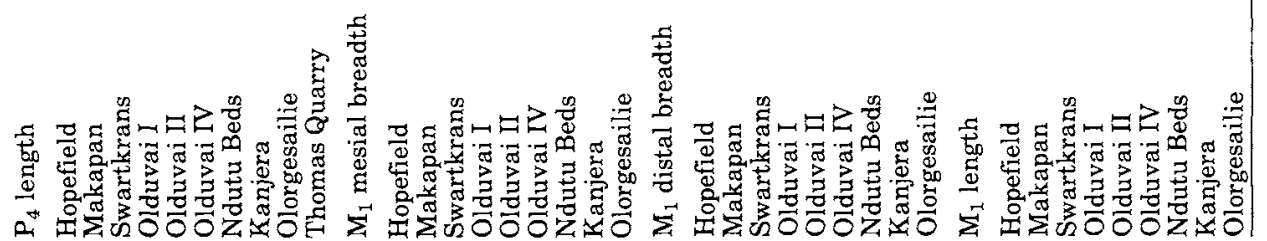




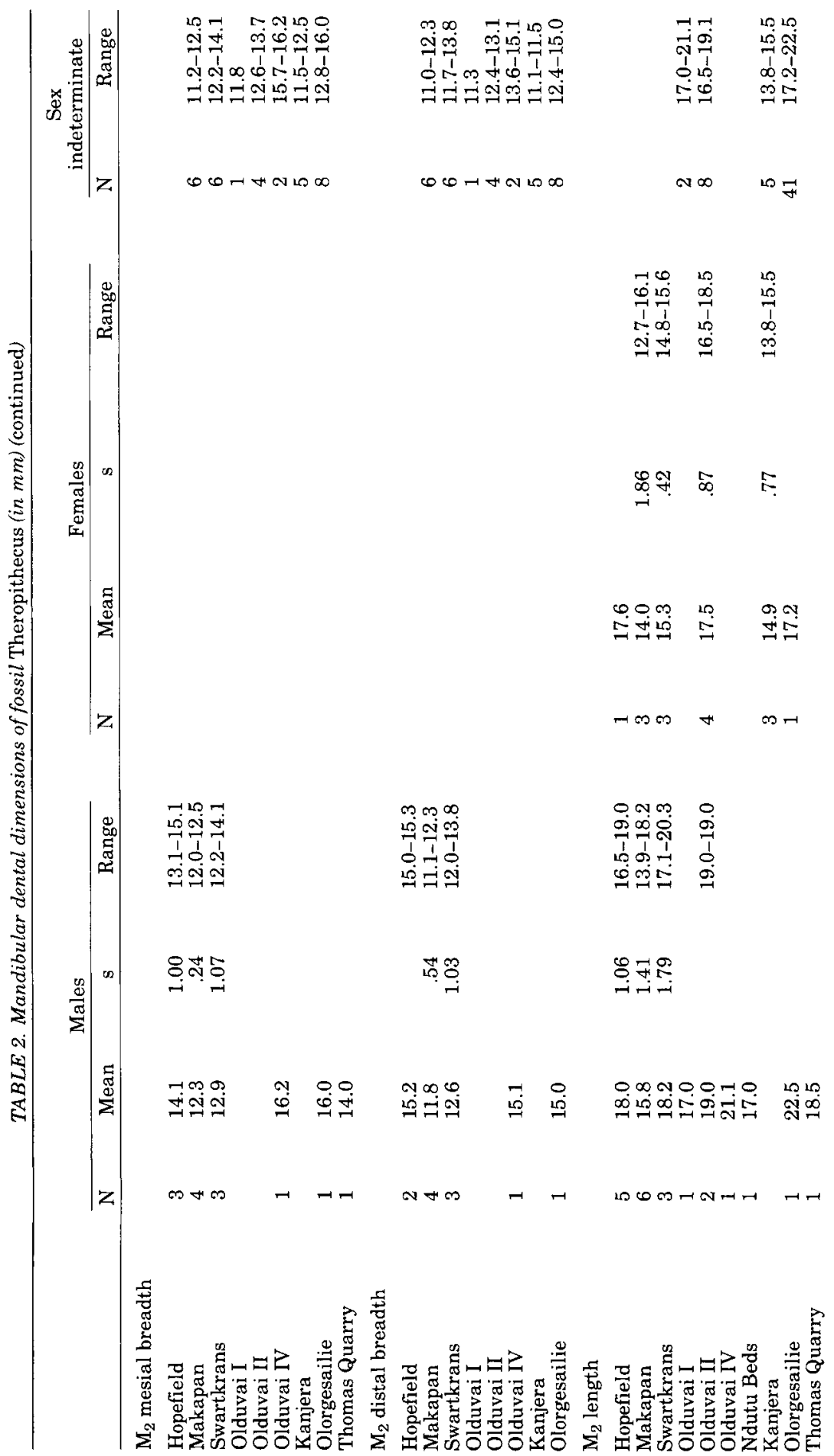




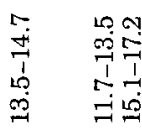

N $\infty \infty$

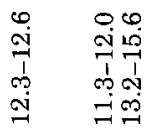

o $\infty \infty$

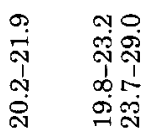

$\infty$

$\infty$
गृ

路 骂

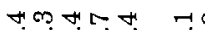

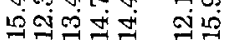

๓ッ⿻コー

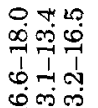

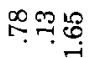

$\stackrel{\substack{\infty \\ \text { ! }}}{\infty}$

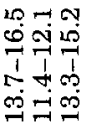

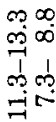

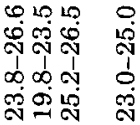

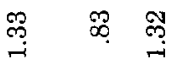

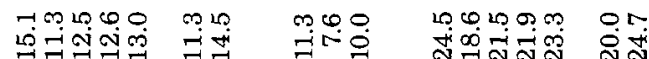

Nกmール

$a n d e$

$m \infty m+n$

$r \cos$

두요

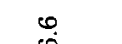

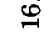

웅

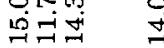

จุำ

$\infty$

"i-

$\infty$

$\sin \pi$

$\rightarrow \infty 0$

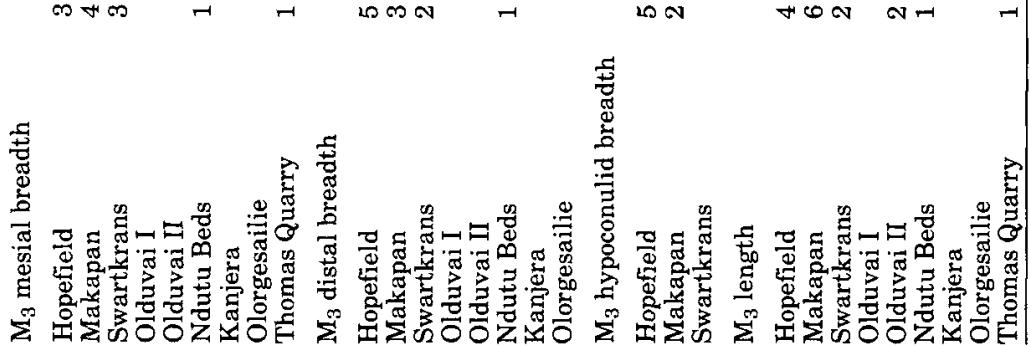

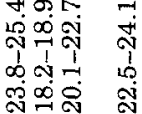

กำ 


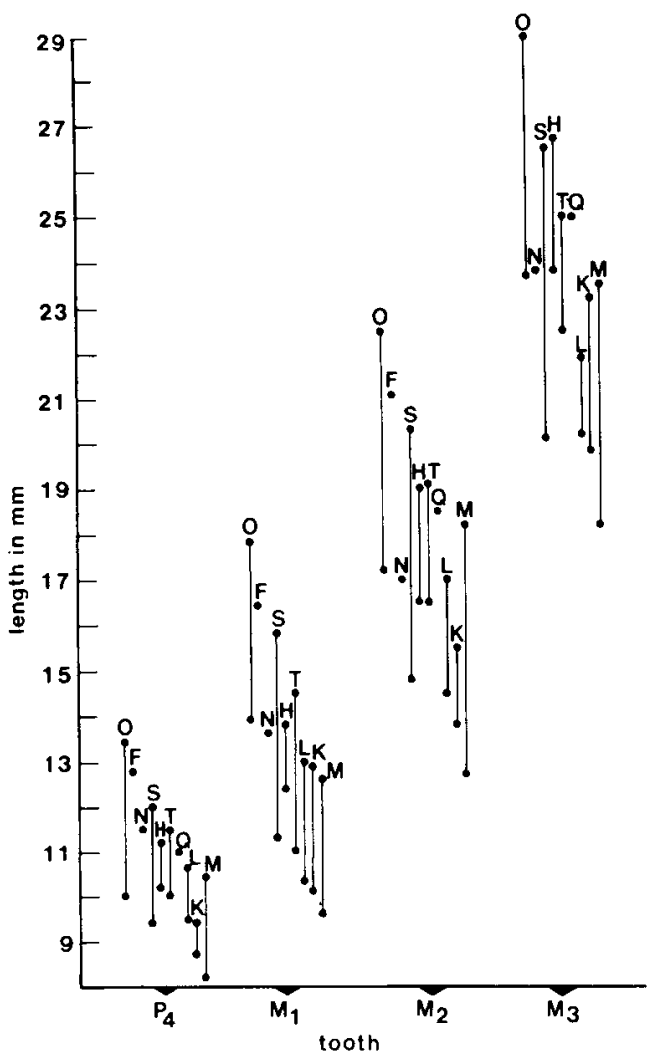

he does not mention the pronounced differences between M.621 (M.626?) and M.3074 noted by Freedman. In addition, Maier finds that one immature male specimen (M.3071) has no development of the fossae.

To determine how much variability might exist in fossa of the mandibular corpus development among fossil Theropithecus, a protocol to measure the depth of the fossa was used on mandibles of modern baboons. Two measurements were made as illustrated in Figure 7: 1) the maximum width of the mandible inferior to the fossae of the mandibular corpora in a coronal plane that was perpendicular to the occlusal plane and contained the most posterior margin of the inferior symphyseal shelf and 2) the distance between the most medial points in the depths of the bilateral fossae of the mandibular corpora. The second measurement was subtracted from the first and the difference was divided by two, resulting in a measurement of the depth of the fossae relative to the most

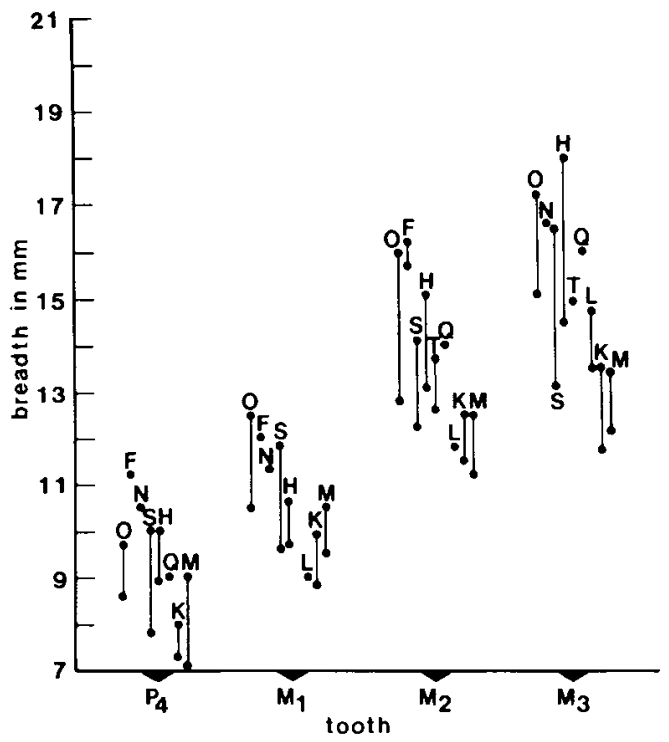

Fig. 5. Ranges of mandibular tooth length (left) and breadth (right) for mixed sex samples of fossil Theropithecus. Data is plotted from Table 2. O. Olorgesailie; F, Olduvai Bed IV; N, Lower Ndutu Beds; S, Swartkrans; H, Hopefield; T, Olduvai Upper Bed II; Q, Thomas Quarry; L, Olduvai Bed I and Lower Bed II; K, Kanjera; $\mathrm{M}$, Makapan.

lateral portion of the lower border of the symphysis. A graph of these data (Fig. 8) gives the following results: 1 ) There was considerable variation within several of the different baboon groups. For instance, fossa depth in male mandrills varied from just greater than zero $\mathrm{mm}$ to greater than $11 \mathrm{~mm}$. 2) All groups of female baboons and some male baboons exhibited values of zero in their range, revealing individuals with little or no development of the fossa. 3) There were some disparities in fossa development between some of the extant baboon groups. For instance, there was not a great amount of overlap in the ranges of male kinda baboons and male chacma baboons, indicating that fossa depth can be used to distinguish some modern groups. 4) A difference in fossa depth between sexes revealed that most females had less fossa development than males.

Variation in fossa depth could not distinguish Hopefield and Makapan Theropithecus when modern baboon variation was consid- 

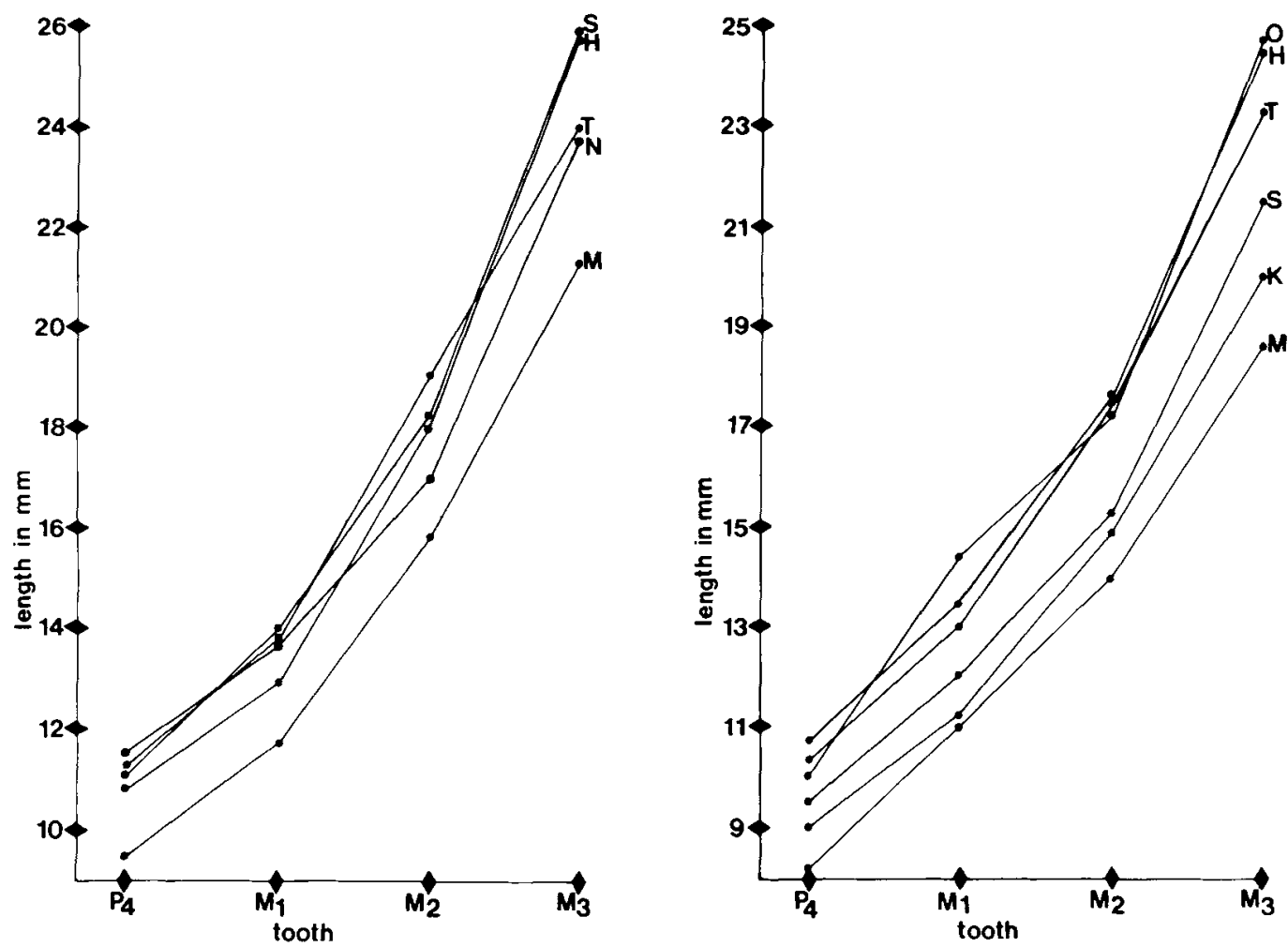

Fig. 6. Means of tooth length for mandibular dentition. Males are on the left; females are on the right. Key is the same as in Figure 5.

ered (Fig. 9). Two specimens from Hopefield (16647 and 1668) were sufficiently complete to allow the depth of their fossae to be measured as in the modern sample, giving figures of $1.1 \mathrm{~mm}$ and $3.2 \mathrm{~mm}$, respectively, and indicating shallow fossa development. As noted, only one Makapan specimen exhibited pronounced fossa development (Freedman, 1957; Maier, 1970). This range of variation in fossa development among Makapan Theropithecus was not unusual compared to most extant male and some female baboon groups. However, understanding the distribution of this trait in the fossils was limited by small sample sizes (see Table 2). A single specimen with well-developed fossae reveals little about the prevalence of this trait among the Makapan Theropithecus population. Likewise, variation in fossa development in Hopefield Theropithecus was likely to be greater than that documented in the few available specimens.
Jolly (1972, p. 69) notes that lower molar structure in Makapan Theropithecus more closely resembles a typical cercopithecine condition than that of Kanjera Theropithecus. Lack of quantification of the relevant features of the molars, makes comparison with the Hopefield dentition difficult. The Hopefield molar pattern is qualitatively sim. ilar to a typical Theropithecus pattern as described by Freedman (1957) and Jolly (1972).

Jolly (1972, p. 69) suggests that Makapan Theropithecus differs from East African forms in that "the sectorial face of the male $P_{3}$ is considerably more elongated relative to its breadth and to general dental size" and that this elongated $P_{3}$ is part of a higher crowned upper canine and longer sectorial premolar complex in male Makapan Theropithecus. The utility of $\mathrm{P}_{3}$ length relative to breadth and overall dental size in separating fossil Theropithecus groups was analyzed by constructing indices of 1 ) $\mathrm{P}_{3}$ breadth divided 

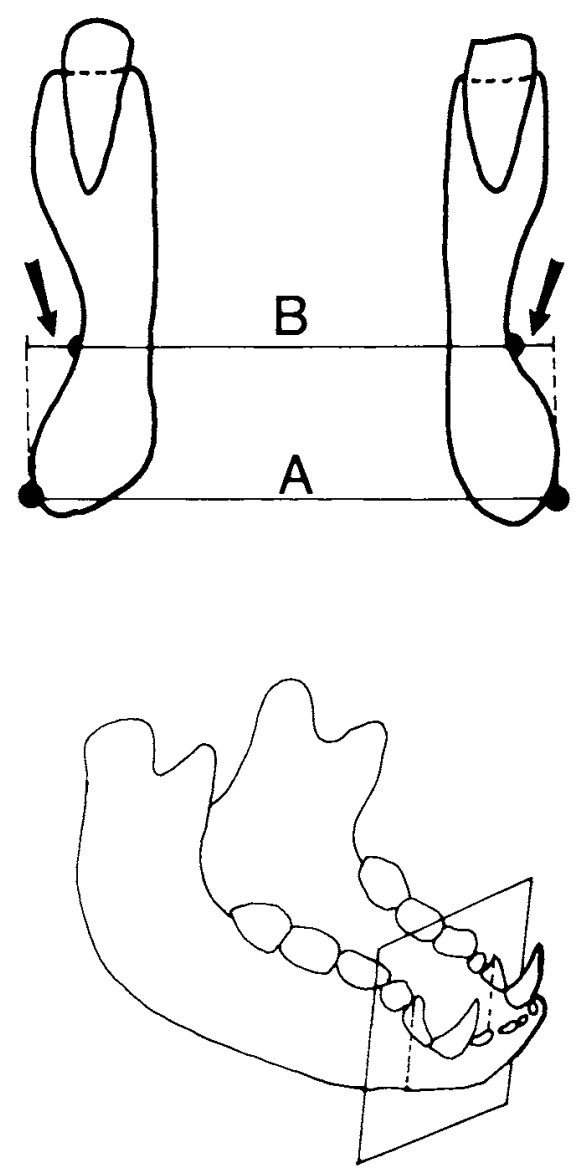

Fig. 7. Measurement of the depth of the fossa of the mandibular corpus. The figure illustrates a cross-section of the mandible in the region of the fossa (at $\mathrm{P}_{3}$ or $\mathrm{P}_{4}$ ), " $A$ " is the maximum width of the mandible inferior to the fossa in a coronal plane that is perpendicular to the occlusal plane and contains the most posterior margin of the inferior symphyseal shelf. " $B$ " is the distance between the most medial points in the depths of the bilateral fossae. Fossa depth is indicated by the arrows and is calculated by subtracting " $B$ " from " $A$ " and dividing the difference by 2 .

by length and 2) $\mathrm{M}_{2}$ length divided by $\mathrm{P}_{3}$ length (Table 3). For comparison, similar indices were constructed for modern anubis and gelada baboons.

The $\mathrm{P}_{3}$ breadth/length indices (Table 3, Fig. 10) range from .26 (Swartkrans) to .53 (Olduvai $I V)$. If the variance from the olive baboon sample $(\mathrm{s}=.03)$ is taken as an estimate of the variance for the fossil baboon groups, the total range of fossil means equals nine stand- ard deviation units, indicating real differences in $\mathrm{P}_{3}$ shape among the fossils. As Jolly (1972) suggested, there is a difference between Makapan and most East African Theropithecus. Makapan has a lower index (.32), indicating a narrower and longer tooth while Olorgesailie (.45), Olduvai IV (.53), and Ndutu Beds (.71) have high indices, indicating wider and shorter teeth. Conversely, Kanjera has an index (.35) that is similar to Makapan's. The index for Hopefield (.38) is intermediate between the Swartkrans, Makapan, and Kanjera groups, on the one hand, and the groups from Olorgesailie, Olduvai Bed IV, and Ndutu Beds, on the other.

The $\mathrm{M}_{2}$ length $/ \mathrm{P}_{3}$ length index results in similar differences between fossil baboons as in the preceding index (Table 3, and Fig. 11). If the variance $(\mathrm{s}=.05)$ of the anubis group is used again as an estimate of variance in fossil groups, the indices have a range of eleven standard deviation units. The East African groups of Olorgesailie, Olduvai IV, and Ndutu Beds have higher values, indicating short $\mathrm{P}_{3} \mathrm{~s}$ relative to molar size, while Makapan, Swartkrans, and one East African group, Olduvai I, have lower values. Hopefield and Olduvai II have indices that are intermediate.

Jolly speculates that differences in male fossil $\mathrm{P}_{3}$ length indicate differences in upper canine crown height. The Theropithecus fossil record is inadequate to demonstrate such differences. Remains from Makapan are restricted to a single isolated upper canine (M.2974) (Freedman, 1960, p. 38). One unworn specimen from Kanjera (F3668) and several from Olorgesailie (no catalog numbers given) are not as high-crowned as those from Makapan (Jolly, 1972). Canines of extant Papio with minimally worn dentitions reveal considerable variation. For example, in 51 wild male anubis baboons with no dentine exposure on the entoconid of the $\mathrm{M}_{2} \mathrm{~s}$, canine height ranges from 22.9 to $49.6 \mathrm{~mm}$ $($ mean $=38.1 \mathrm{~mm}, \mathrm{~s}=5.4 \mathrm{~mm})$. Similar statistics are found for other extant baboon groups. Clearly, larger sample sizes and a quantitative approach are necessary to show canine height differences between fossil Theropithecus groups.

The assumption that the sectorial face of the $P_{3}$ is indicative of canine crown height seems intuitively obvious, but is difficult to demonstrate. For instance, in modern Papio, both canine height and $\mathrm{P}_{3}$ length are positively correlated with each other and facial 

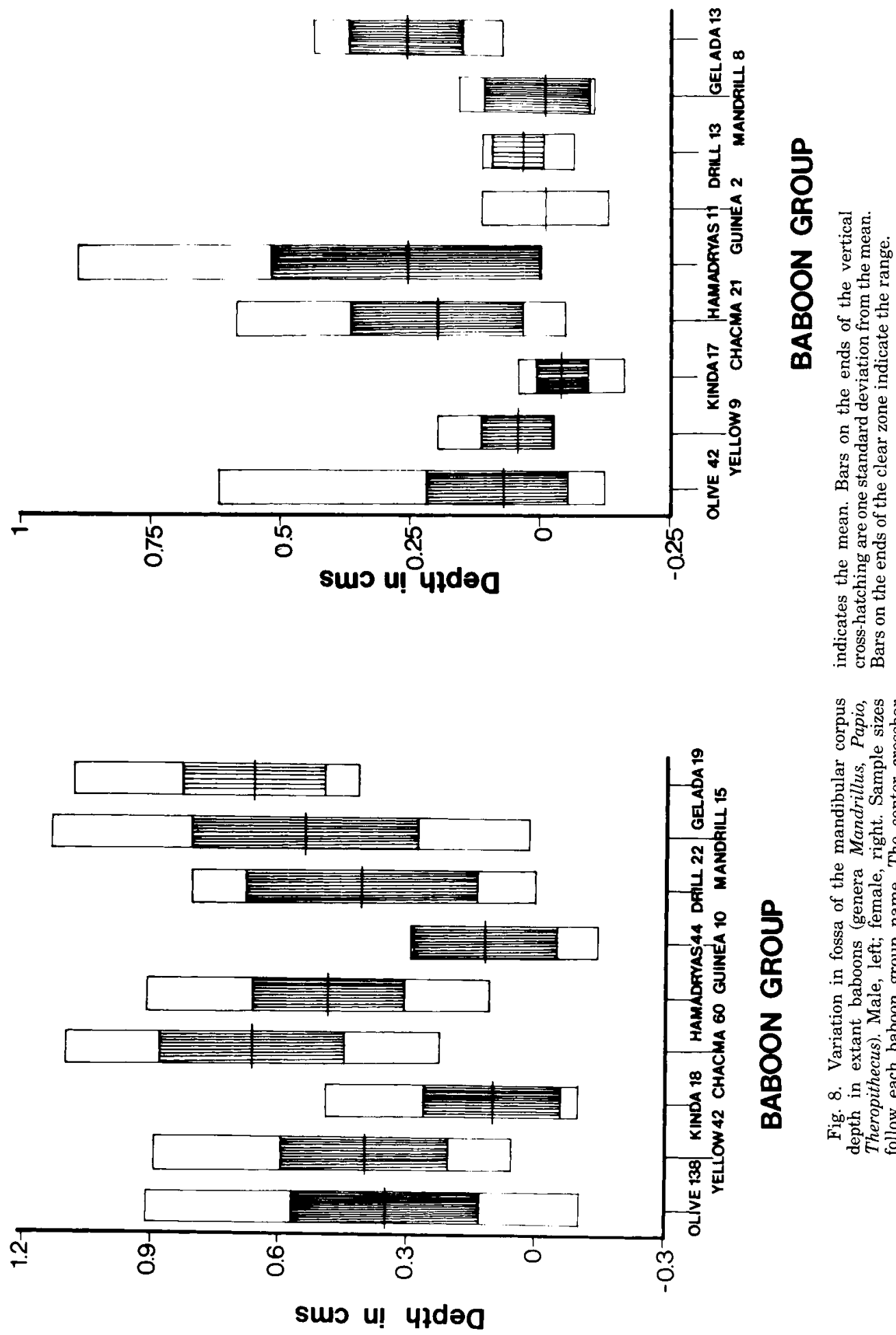

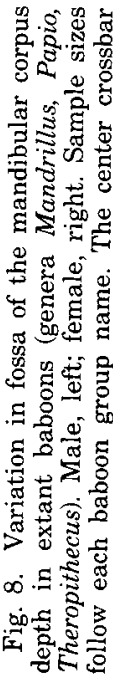




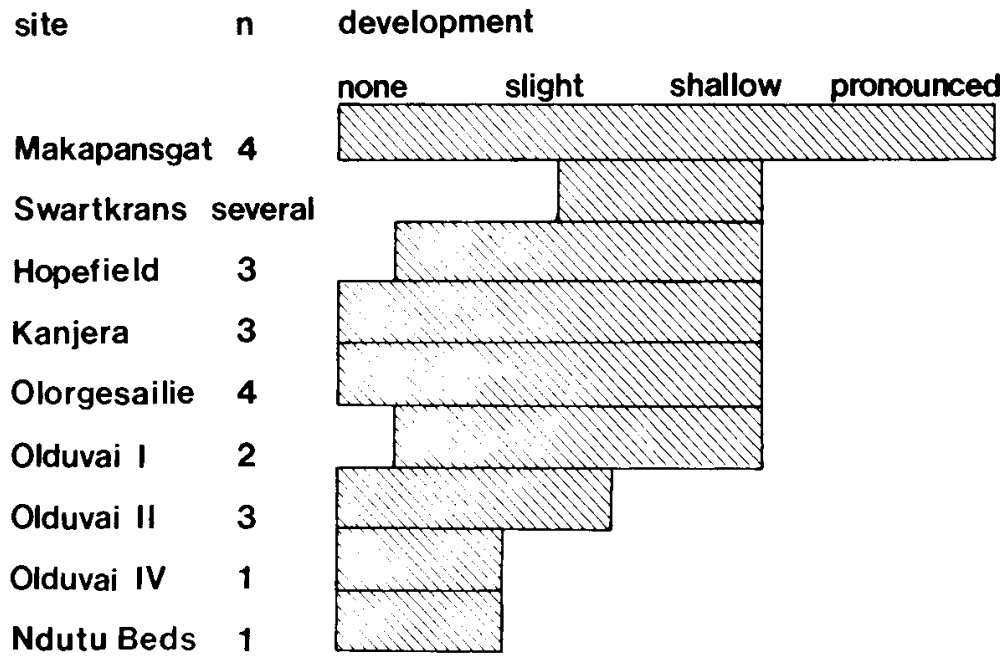

Fig. 9. Variation in fossa of the mandibular corpus depth in fossil Theropithecus. The qualitative assess-

ment of fossa development for each site is further described in the test.

TABLE 3. Male $P_{3}$ indices

\begin{tabular}{|c|c|c|c|c|}
\hline & $\mathrm{N}$ & Mean & $\mathrm{s}$ & Range \\
\hline \multicolumn{5}{|c|}{$P_{3}$ breadth/length index } \\
\hline $\begin{array}{l}\text { Hopefield } \\
\text { Makapan } \\
\text { Swartkrans } \\
\text { Olduvai IV } \\
\text { Ndutu Beds } \\
\text { Kanjeral }\end{array}$ & $\begin{array}{l}1 \\
4 \\
1 \\
1 \\
1\end{array}$ & $\begin{array}{l}.38 \\
.32 \\
.26 \\
.53 \\
.71 \\
.35\end{array}$ & .06 & $.28-.42$ \\
\hline $\begin{array}{l}\text { Olorgesailie } \\
\text { olive }^{3}\end{array}$ & 13 & .43 & .04 & $.38-.48$ \\
\hline $\begin{array}{l}\text { baboons } \\
\text { gelada }^{3}\end{array}$ & 138 & .28 & .03 & $.28-.43$ \\
\hline baboons & 19 & .36 & .02 & $.32-.39$ \\
\hline \multicolumn{5}{|c|}{$\mathrm{M}_{2}$ length $/ \mathrm{P}_{3}$ length index } \\
\hline $\begin{array}{l}\text { Hopefield } \\
\text { Makapan } \\
\text { Swartkrans } \\
\text { Olduvai I } \\
\text { Olduvai II } \\
\text { Olduvai IV } \\
\text { Ndutu Beds } \\
\text { Olorgesailie } \\
\text { olive }^{3}\end{array}$ & $\begin{array}{l}1 \\
4 \\
1 \\
1 \\
2 \\
1 \\
1\end{array}$ & $\begin{array}{r}.95 \\
.70 \\
.68 \\
.77 \\
1.01 \\
1.19 \\
1.43 \\
1.26\end{array}$ & .14 & $.58-.90$ \\
\hline $\begin{array}{l}\text { baboons } \\
\text { gelada }^{3}\end{array}$ & 139 & .58 & .05 & $.41-.76$ \\
\hline baboons & 19 & .67 & .04 & $.60-.72$ \\
\hline
\end{tabular}

${ }^{1}$ Index calculated from means; data for individual animals are not available.

${ }^{2}$ Figures taken from Leakey and Leakey (1973).

${ }^{3} \mathrm{P}_{3}$ length in modern sample is not total tooth length as in the fossil sample but is the length of the sectorial surface of the tooth measured along the long axis of this surface. 


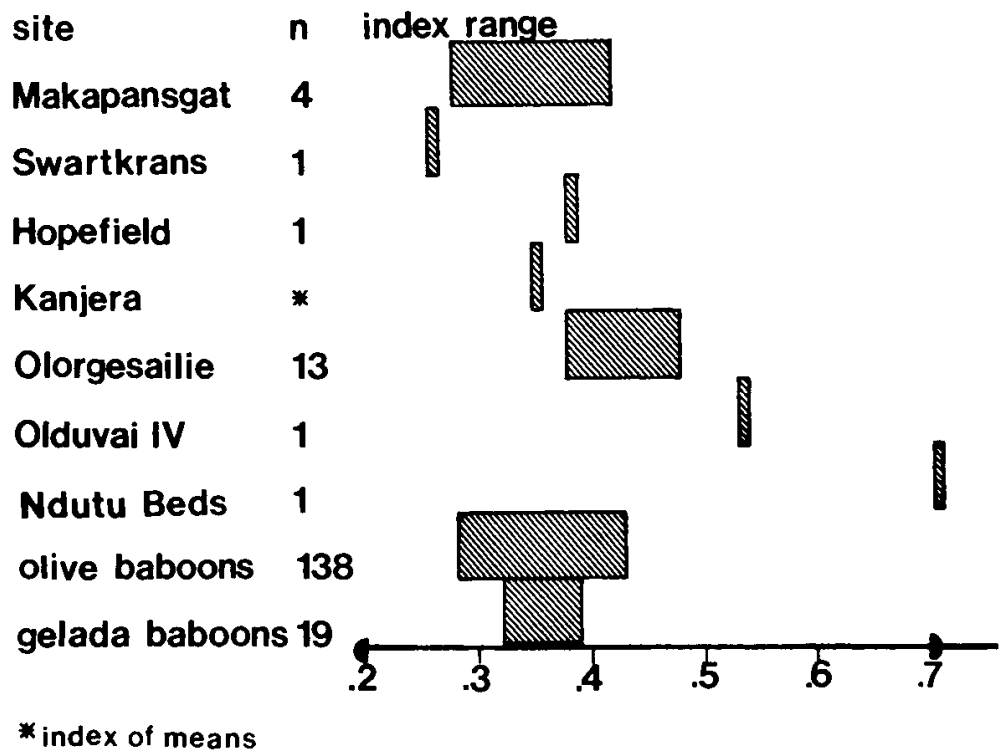

Fig. 10. Ranges of $P_{3}$ breadth/length index for fossil Theropithecus and extant baboons. Indices are calculated from individual tooth measurements. Olorgesailie measurements are taken from Leakey and Leakey (1973). The Kanjera index is calculated from means because data for individual animals are unavailable. $P_{3}$ length for extant olive baboons (Papio anubis) and gelada baboons (Theropithecus gelada) is not the total length as in the fossil sample but is the length of the sectorial surface of the tooth measured along the long axis of this surface.

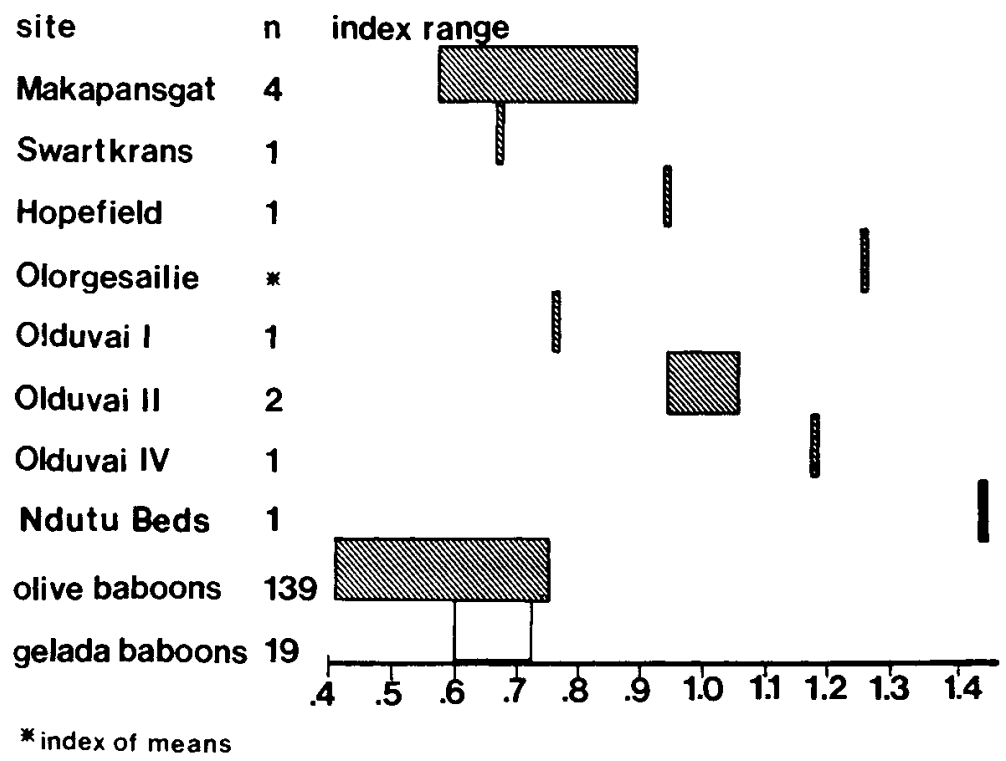

Fig. 11. Ranges of male $\mathrm{M}_{2}$ length/ $\mathrm{P}_{3}$ length index for fossil Theropithecus and extant baboons. Indices are calculated from individual tooth measurements. The Olorgesailie index is calculated from means because data for individual animals are unavailable. $P_{3}$ length for extant olive baboons ( $P$. anubis) and gelada baboons ( $T$. gelada) is not the total tooth length as in the fossil sample but is the length of the sectorial surface of the tooth measured along the long axis of this surface. 
length (Dechow, 1980). Thus, correlation between canine height and $\mathrm{P}_{3}$ length may be related to changes in facial size. Arguments that a correlation in the length of the sectorial surfaces of the canine-premolar complex are of functional necessity await further study.

The slope of the superior symphyseal shelf does not readily distinguish Makapan and Hopefield Theropithecus. Freedman (1960, p. 43) notes that in M.621 (M.626?), "the symphyseal region slopes down very steeply between the premolars and behind the incisors." Jolly (1972, p. 68), citing Freedman $(1957,1960)$, also remarks that in Makapan Theropithecus, "the internal surface of the symphysis, instead of being flat, slopes downwards rather abruptly between the premolars." Neither author notes any specimens other than M.626 as having this trait. On the contrary, Freedman (1957, p. 204) states that while M.626 appears to differ consider. ably from M.201, actually this difference is "of no great magnitude, . . . because in M.626 the avleolar part of the symphysis is broken off and the mandibular fossae are considerably deeper." Maier (1970, p. 85) discusses the differences between two specimens (M.3071 and M.3074) in the development of the symphyseal area, including the superior shelf. He correctly points out that the underdevelopment of this area in M.3071 is a result of immaturity but he does not mention that the internal symphyseal area of either specimen is unusual. In general, the internal symphyseal area of Makapan Theropithecus, with the possible exception of M.626, does not differ from Theropithecus from Hopefield or other localities.

No studies of fossil Theropithecus have attempted to quantify symphyseal features that possibly represent differences between groups. To estimate what symphyseal variability might be like in the fossils, measurements were taken on 19 adult male Theropithecus gelada crania (Fig. 12). Data were collected using a diagraph to measure the position (via cartesian coordinates) of 1) the posterior extent of the superior symphyseal shelf, 2) the posterior extent of the inferior symphyseal shelf, 3) infradentale, 4) the tip of the buccal cusp of the $\mathrm{P}_{4} \mathrm{~s}$ and 5) several points approximating the orientation of the occlusal plane. From these data, measurements were derived including 1) an approximation of the slope of the superior symphyseal shelf relative to the occlusal plane
(Fig. 12), and 2) the distances between posterior extents of the symphyseal shelves and the $\mathbf{P}_{4}$ relative to the occlusal plane. Results show that the angle of the symphyseal shelf in extant Theropithecus varies by a large amount (Fig. 12) from $15.1^{\circ}$ to $39.9^{\circ}$ (mean $=26.2^{\circ}, \mathrm{SD}=5.7^{\circ}$ ). Comparisons with data from Makapan fossils would be interesting.

The position of the posterior extent of the superior symphyseal shelf varies from 7.5 $\mathrm{mm}$ posterior to $7.5 \mathrm{~mm}$ anterior to the apex of the buccal cusp of $\mathrm{P}_{4}$ (mean $1.8 \mathrm{~mm}$ anterior, S.D. $=3.3 \mathrm{~mm}$ ). Qualitatively, the posterior extent of the superior symphyseal shelf in extant adult male Theropithecus ranges from distal $P_{3}$ to mesial $M_{1}$ but usually lies near mesial $\mathrm{P}_{4}$. The position of the posterior extent of the inferior symphyseal shelf varies from $1.0 \mathrm{~mm}$ anterior to $13.0 \mathrm{~mm}$ posterior to the apex of the buccal cusp of $\mathrm{P}_{4}$ (mean $=$ $6.2 \mathrm{~mm}$ posterior, S.D. $=3.6 \mathrm{~mm}$ ). Qualitatively, the inferior shelf extends posteriorly from mesial $\mathrm{P}_{4}$ to distal $\mathrm{M}_{1}$ but is usually located near distal $\mathrm{P}_{4}$ or mesial $\mathbf{M}_{1}$. Juvenile baboons have less-developed symphyseal shelves than adults, thus increasing the total range of variability.

The internal surface of the symphyseal area is present in two Hopefield mandibles (16647 and 16648). The differences between them are similar to those between an immature and a mature specimen from Makapan (Maier, 1970). The immature specimen, 16647, has an underdeveloped upper symphyseal shelf that does not project as far posteriorly as that of 16648 , the adult specimen. One hemimandible from Hopefield, 16649, resembles 16647 in the available features of the internal surface of the symphysis.

The sparse data on corpus depth relative to mandibular length in Theropithecus from Makapan, Hopefield, and other localities limit any possible conclusions (Fig. 13). Jolly (1972, p. 68) produces a ratio of the depth of the corpus below the median buccal cleft of $\mathrm{M}_{2}$ divided by mandibular molar row length for female specimens from Makapan (.95), Olduvai Bed I (.71), Kanjera (.69), and Olorgesailie (.63). One female specimen from Hopefield (16649) has a ratio of .62, similar to the low ratio from Olorgesailie and most different from Makapan. The meaning of these differences is unclear; a sample of 14 adult male anubis baboons have a range for this index nearly as large as that among the fossil forms (Fig. 13). Among Makapan males, ratios of .69 for M.201 and .64 for M.626 were 

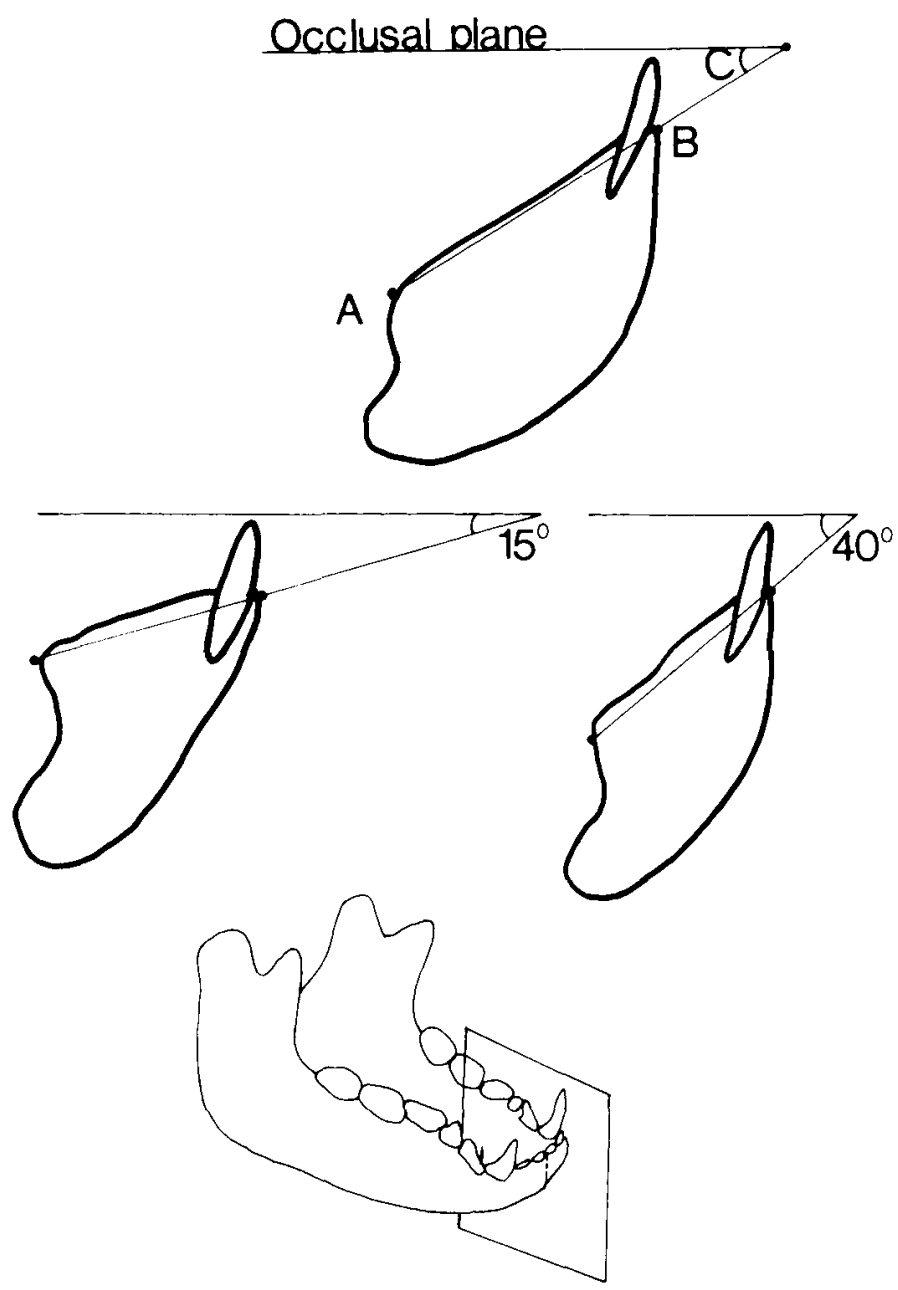

Fig. 12. Range of variation for superior symphyseal slope angle in Theropithecus gelada. The top figure illustrates that the superior symphyseal slope angle (C) was computed by measuring the angle between the intersection of the midsagittal plane and the occlusal plane and a line that intersects the posterior extent of the superior symphyseal shelf (A) and infradentale (B). The middle figures show the range of variation for a sample of 19 male gelada baboons $\left(\right.$ mean $=26^{\circ} ; \mathrm{s}=6^{\circ}$ ). calculated from Freedman's (1957, p. 206) data. The Hopefield male mandible, 16648 has a ratio of .79 . Contrary to the female condition, the ratio among males is larger in the Hopefield than Makapan specimens. This variability calls into question the relevance of this index.

The anterior deepening of the mandible is also not a good criterion to separate Makapan and Hopefield Theropithecus. Jolly (1972, p. 68) discusses that the occlusal plane and the lower border of the mandibular corpus are parallel in most fossil Theropithecus. M.626 is an exception as "the inferior border and the occlusal plane can be seen to diverge anteriorly quite strongly." Jolly's description is verified by mandibular height data (Freedman, 1957, p. 206). According to Freedman (p. 205), M.201 is similar to M.626 in the anterior deepening of the mandibular corpus, but data (p. 206) show that M.201 has a similar depth below the distal molar $(33 \mathrm{~mm})$ and premolars (34 $\mathrm{mm}$ ) (Freedman, 1957). Other male and female specimens examined 


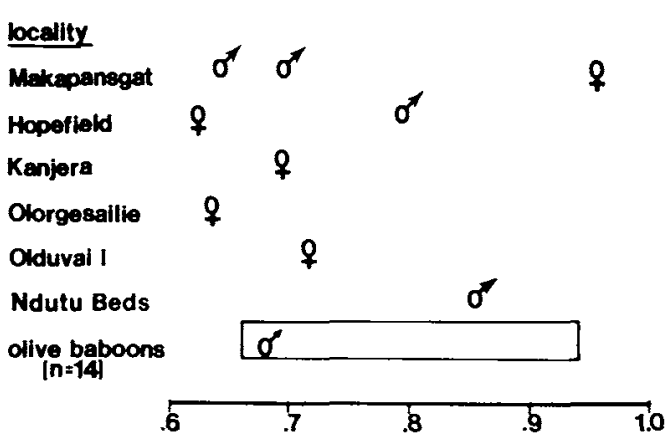

Fig. 13. Mandibular corpus depth/molar row length index in fossil Theropithecus. Sex of fossil specimens is noted by the appropriate sign. Range of sample of extant olive baboons ( $P$. anubis) is added for comparison. Some values (see text) are taken from Jolly (1972:68).

by Freedman $(1957,1960)$ are not sufficiently complete to assess this feature. Maier (1970) discusses three mandibles, of which one, M.3073, has mandibular corpora that decrease in depth anteriorly. This feature is not discussed for an immature male mandible (M.3071) or an adult male mandible (M.3074), but a plate (Maier, 1970, his Fig. 20) shows that M.3071 has a nearly parallel occlusal plane and lower border of the left corpus. The adult mandible is not figured. The available data indicate that this trait is variable in Makapan Theropithecus. The occlusal planes of Hopefield Theropithecus are nearly parallel to the lower borders of the mandibular corpora (see data for 16648 and 16649).

Data are insufficient to judge if incisal breadth is greater at Makapan than at Hopefield and other sites. The Hopefield upper incisor (16680) is very worn and only an estimate of incisor root socket width, which is not comparable to dimensions given by Maier (1970) for Makapan fossils, can be made on the best preserved mandible (16648). Some data on incisal breadth in Olorgesailie and Olduvai Bed II fossils (Leakey and Leakey, 1973) indicate smaller teeth than in the Makapan remains despite their smaller overall size (Fig. 14).

The most consistent differences between Makapan and Hopefield Theropithecus are in the size of the teeth and jaws (Table 2, Figs. $5,6)$. On the average, dental and gnathic size is greater in the Hopefield specimens despite overlap of the ranges for many measurements.
In summary, size is the clearest difference between Hopefield and Makapan fossils. The relative dimensions of the $\mathrm{P}_{3} \mathrm{~s}$ also separate Makapan from other Theropithecus, although not particularly from the Hopefield group. Other proposed differences such as the molar cusp morphology, upper male canine crown height, relative mandibular corpus depth, and incisor breadth require further data to be evaluated. Other suggested differences in 1) fossa of the mandibular corpus size and depth, 2) upper symphyseal shelf slope, and 3) depth of the anterior relative to the posterior mandibular corpus, cannot be shown to be real given the limited fossil sample sizes and the morphological variation in the fossil and modern baboon groups. For each of these traits, a single specimen, M.626, varies from the morphology of other specimens from Makapan, Hopefield, and other localities. The taxonomic position of this specimen to other Makapan Theropithecus should be reexamined.

Swartkrans: Theropithecus remains from Swartkrans, which consist of 20 maxillary and mandibular fragments including a female skull, SK561 (originally crushed but now reconstructed by Ronald Clark and Eric Delson) are from a minimum of 17 individuals and derive from a common geographical member (Member 1) (Freedman, 1957).

Two forms of fossil Theropithecus may be present at Swartkrans as indicated by the large male $\mathrm{P}_{4}$ of SK569 (Freedman, 1957) and differences in muzzle height and maxillary fossa depth (Jolly, 1972). At present, the sample sizes of the Swartkrans fossils are too small to make taxonomic distinctions based on tooth dimensions (Freedman, 1957).

Differences in muzzle dimensions are suggested between two fossils, SK561 and SK563. According to Freedman (1960, p. 43), SK561, a badly crushed female skull, has no maxillary fossae, while SK563, a fragmentary female maxilla, has a muzzle that is "rather higher" than some East African fossil Theropithecus and maxillary fossae that are "deep." Surprisingly, Freedman in his original (1957, p. 208) description of the max illary fossa of these specimens states that "there is only a slight excavation in SK563 and none at all in SK561." This later description is supported by appropriate figures (Freedman, 1957, Plate XLII). Jolly (1972) suggests that the alleged difference in maxillary fossa size between SK561 and SK563 leads to a question of "whether more than 


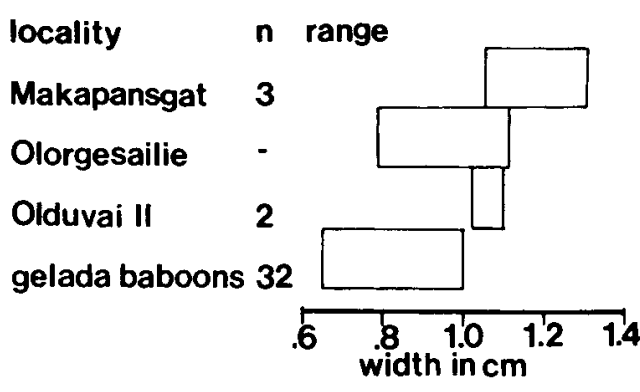

Fig. 14. Range of mandibular incisal width in fossil Theropithecus. Measurement is the combined width of the $I_{1}$ and $I_{2}$. The Olorgesailie range is based on the added ranges of the individual teeth and is taken from Leakey and Leakey (1973). The range of variation for a sample of 32 gelada baboons ( $T$. gelada) is added for comparison.

one form of Simopithecus occurs at Swartkrans" because "this feature is not generally so variable within populations of living Cercopithecoidea." Jolly's supposition was analyzed by documenting maxillary fossa depth in groups of extant baboons. This depth was measured by subtracting the minimum distance across the muzzle between the apices of the paracones of the $\mathrm{M}_{2} \mathrm{~s}$ and dividing this difference by two. The variation in baboon groups (same groups as in Fig. 8) ranged from moderate to large. For instance, in 19 male gelada baboons, maxillary fossa depth ranged from $4.65 \mathrm{~mm}$ to $9.45 \mathrm{~mm}$. while in 42 female anubis baboons, maxillary fossa depth ranged from less than zero to $10.6 \mathrm{~mm}$. Thus, some female anubis baboons had fossae as developed as the deepest fossae of male gelada baboons while others had no development. Given this range of variation in extant baboons, variation between SK561 and SK563 is not adequate for taxonomic distinctions.

Fossil Theropithecus from Swartkrans and Hopefield have similar morphology. The Swartkrans male and female mandibles have "only a very shallow" fossa of the mandibular corpus (Freedman, 1957, p. 209) similar to the Hopefield specimens (Fig. 9). One specimen, SK402, a female mandible, has a corpus that does not deepen anteriorly but is of constant height (see Freedman, 1957, Table $16 \mathrm{~b}$ ), as in the Hopefield specimens. The cheek teeth from Swartkrans are unremarkable, resembling those from Kanjera although the male $\mathrm{P}_{3}$ "is relatively longer than that of Kanjera, though not as extreme as in the Makapan male (Jolly, 1972, p. 70)." This impression is not wholly substantiated by data (Table 3, Fig. 10), which indicates that the male $\mathrm{P}_{3}$ is longer relative to its width in the Swartkrans specimen than in specimens from other localities. The Hopefield male $\mathrm{P}_{3}$ is not extreme in this feature among the fossil forms.

The ranges for Hopefield and Swartkrans mandibular tooth size overlap (Fig. 5). Likewise, the means of the male tooth dimensions are similar (Table 2, Fig. 6), but the means for Swartkrans female tooth length are consistently smaller than those from Hopefield (two-tailed $\mathrm{T}$ test for $\mathrm{P}_{4}: \mathrm{t}=2.65, \mathrm{P}<.15$; $\mathrm{M}_{1}: \mathrm{t}=2.72, \mathrm{P}<.1 ; \mathrm{M}_{2}: \mathrm{t}=4.60, \mathrm{P}<.025 ;$ $\mathrm{M}_{3}: \mathrm{t}=3.36, \mathrm{P}<.05$ ) indicating a greater degree of sexual dimorphism at Swartkrans than at Hopefield in tooth size and possibly other dimensions, such as skull size.

Kanjera: The Kanjera Theropithecus sample consists of 21 cranial and mandibular pieces and 69 postcranial fragments (Andrews, 1916; Hopwood, 1936; Leakey, 1943; Leakey and Whitworth, 1958; Jolly, 1972). Remains comparable to Hopefield consist of an almost complete female mandible (M11539), a female juvenile mandible (F3398), three corporal fragments each with several teeth (M18770, M11541, M19011), a male symphyseal fragment (unregistered), and a male lower canine (M18729) (Jolly, 1972).

The above material indicates no substantial qualitative differences from the Hopefield specimens. The fossa of the mandibular corpus (Fig. 9) ranges from absent (F3398) to "only the slightest trace" (M11539) to "shallow" (M11541) (Jolly, 1972) on specimens that are respectively female, juvenile, and unknown. Appropriate remains of adult males, which usually have the greatest fossa development, are not present.

Differences in mandibular morphology among Kanjera specimens can be attributed to age (Jolly, 1972, p. 18-19). The juvenile corpus (F3398) is more lightly built than the adult female (M11539). The internal aspect of the juvenile symphysis is "less backwardly extended relative to the dentition than in the adult individual."

The chief difference between Kanjera and Hopefield specimens is size. Other features such as $\mathrm{P}_{3}$ breadth/length index (Table 3 , Fig. 10) and relative corpus depth (Fig. 13) (see Makapan discussion) are similar in 
Hopefield and Kanjera specimens. The Hopefield dental dimensions are larger than Kanjera's with no overlap in the ranges except for $M_{1}$ dimensions. Due to the incompleteness of the specimens from Kanjera, none can be positively identified as males, according to Jolly's (1972) criterion for sexing, morphology of the canine-sectorial premolar complex. However, some of the specimens listed in Table 2 under "Total Sample" (see also Fig. 5) are probably male. The means of the Hopefield female mandibular teeth lengths are all greater than any Kanjera measurement.

Olorgesailie: Nine mandibular and cranial fragments, over 100 postcranial fragments (Jolly, 1972), and 722 isolated teeth (Leakey and Leakey, 1973) of fossil Theropithecus are reported from Olorgesailie. Shipman and colleagues (1981) argue that the pattern of breakage and representation of these Theropithecus remains suggest that these animals were butchered or perhaps hunted by hominids. Fossils comparable to Hopefield remains are a symphysis and right mandibular corpus of an adult male (KNM-OG 0004) and mandibular corpora of a young adult female (KNM = OG 0002), a young adult male (KNMOG 0005) and two juvenile males (KNM-OG 10003 and KNM-OG 0781).

Jolly (1972, pp. 45-46) lists several features that may distinguish Olorgesailie from other fossil Theropithecus, namely: 1) the development of extra vertical grooves on the molars and premolars; 2) the relative shortness of the male $\mathbf{P}_{3}$ compared to Kanjera Theropithecus; and 3) lower-crowned male canines relative to Kanjera. Data (Table 3, Fig. 10) demonstrate the relative shortness of $\mathrm{P}_{3}$ in Olorgesailie Theropithecus. Canine height at Olorgesailie cannot be evaluated because data are unavailable although Jolly (1972) and Leakey and Leakey (1973) note relevant specimens. (For further discussion, see section of this paper on Makapan).

Data on the number of vertical grooves on the cheek teeth of Olorgesailie Theropithecus are unavailable, but should be accessible, given the large number of teeth available among the Olorgesailie remains. One hypothesis that should be tested is that the larger number of vertical grooves on the cheek teeth of Olorgesailie Theropithecus is related to the larger size of this form.

In summary, Olorgesailie and Hopefield Theropithecus differ little. The fossa of the mandibular corpus (Fig. 9) varies from "no trace" on KNM-OG 0004 to "shallow" on
KNM-OG 0003 (Jolly, 1972, p. 44). The structure of the symphysis (Jolly, 1972) is also similar to the Hopefield remains. The Vshaped outline of KNM-OG 0004 (Jolly, 1972, Plate 19) is similar to the shape of the adult male mandible (16648) from Hopefield.

Tooth size is similar in Hopefield and Olorgesailie fossil Theropithecus (Figs. 5, 6), although the Olorgesailie ranges are larger indicating a few individuals with absolutely larger measurements for most dimensions.

Olduvai: Fossil Theropithecus have been recovered from various sites in Beds I through $\Gamma V$ and the lower Ndutu Beds of Olduvai Gorge in Tanzania. Mandibular and dental fragments comparable to Hopefield remains number 5 from Bed I and Lower Bed II (M14937; M14938; OLD/63,050; OLD/ 63,283; 067/6640), 7 from Upper Bed II (BK II; $1953 / 117$; M14953; 580,57; OLD/63,3366; $067,2771 ; 067,5603), 1$ definite (OLD/69,5186) and 1 questionable (OLD/69,S.194) from Bed III, 1 from Bed IV (M14680), and 1 from the lower Ndutu Beds (OLD/1472,57) (Leakey and Whitworth, 1958; Jolly, 1972; Leakey and Leakey, 1973; Hay, 1976). Remains from Bed III are too poorly preserved to allow salient comparisons (Leakey and Leakey, 1973) and are not considered further.

Bed I and Lower Bed II.. Jolly (1972) and Leakey and Leakey (1973) suggest several traits of the three best preserved Bed I/Lower Bed II fossils to distinguish them from the fossils of Upper Bed II, Bed IV, and other East African sites. Leakey and Leakey (1973, p. 118) list traits of several fragments (OLD/ 63,3050-right mandibular corpus fragment; OLD/63,283-left mandibular corpus fragment; and OLD/63,3064-upper canine), that probably constitute a single individual including 1) very large canines relative to posterior dentition; 2) long sectorial cusps on $\mathrm{P}_{3}$; 3) shallow mandibular corpus deepening anteriorly; 4) lower crowned teeth; and 5) smaller size. Jolly (1972, p. 63) notes that an adult female right mandibular corpus (M14938) from site DKI, like one described by Leakey and Leakey (1973), has a mandibular corpus that deepens anteriorly and a more steeply sloping anterior symphyseal shelf than female specimens from Olorgesailie, Kanjera, or Olduvai Upper Bed II. Both mandibular fragments (M14938 and OLD 63,3050 ) have a fossa of the mandibular corpus.

Some of the above features are better than others for establishing differences between remains from Olduvai Bed I/Lower Bed II 
and other sites. For instance, the presence of lower crowned cheek teeth is doubtful. Leakey and Leakey (1973, p. 104) claim this for OLD/63,3050 and they (1973, p. 104) also suggest that M14937 has dental morphology that "is not inconsistent with other female specimens from Bed I." However, Jolly (1972, p. 63) states, regarding the fossil dentitions from Bed I/Lower Bed II (including M14937), that "the structure of the molars and premolars shows no differences from other populations which could not be attributed to individual variation." Jolly also finds that Bed I/Lower Bed II teeth are smaller than those from Upper Bed II and Bed IV, suggesting that the difference from other sites is size-related. In any case, data on cheek tooth height are unavailable, making settlement of this issue impossible. However, it is illustrative that cheek tooth height varies greatly in modern baboons. Hypoconid height from the enamel-dentin juncture to the tip of the hypoconid and tooth length were measured on pristine $\mathrm{M}_{2} \mathrm{~s}$ of extant baboons. Thirty male anubis baboons ranged in crown height (hypoconid height) from $8.2 \mathrm{~mm}$ to $12.6 \mathrm{~mm}$ (mean $=10.1$, S.D. $=1.0)$ and in relative crown height (hypoconid height divided by tooth length) from 6.6 to 9.2 (mean $=7.4$, S.D. $=.6$ ). Thirteen male gelada baboons ranged from $8.9 \mathrm{~mm}$ to $10.9 \mathrm{~mm}$ (mean = $10.2 \mathrm{~mm}$, S.D. $=.5 \mathrm{~mm}$ ) in crown height and from 6.6 to 8.9 (mean $=7.8$, S.D. $=.6$ ) in relative crown height. Other extant baboon groups exhibit similar variation. Comparable amounts of variation might be expected among the fossils.

The male $\mathrm{P}_{3}(\mathrm{OLD} / 63,3050)$ (Leakey and Leakey, 1973) resembles fossils from Swartkrans and Makapan in being long relative to $\mathrm{M}_{2}$ length (see Table 3, Fig. 10). The fossil contrasts with the shorter $\mathrm{P}_{3}$ of the Hopefield, Olorgesailie, and Olduvai Upper Bed II and Bed IV remains. Likewise, a relatively high-crowned upper canine might be found in Bed I/Lower Bed II Theropithecus. However, data are not available for a single isolated upper canine $(\mathrm{OLD} / 63,3064-$ probably from the same individual as $\mathrm{OLD} / 63,3050$ ). Modern baboons reveal considerable variation in canine crown height (see earlier discussion).

Differences between Olduvai Bed ILLwer Bed II and Hopefield Theropithecus in the anterior deepening of the mandibular corpus are small. Jolly (1972, p. 63) describes the adult female mandibular fragment (M14938) as having a mandibular corpus that "deep- ens appreciably anteriorly reaching its greatest depth below the mesial cusp of the $\mathrm{M}_{1}$." However, this deepening is not as pronounced as that exhibited by M.626 from Makapan (see Jolly, 1972, Plate 1b; Freedman, 1957, p. 206). Likewise, OLD/63,3050 has some deepening of the mandible anteriorly (Leakey and Leakey, 1973, Plate 1) while the Hopefield mandibular corpora do not.

The presence of the fossa of the mandibular corpus is a small difference of questionable significance between Olduvai Bed L/Lower Bed II and Hopefield Theropithecus (Fig. 9). The female fragment $(\mathrm{OLD} / 63,3050)$ has only a "slight depression" representing the fossa (Leakey and Leakey, 1973, p. 103) while the male fragment (M14938) has "a distinct, though not deep" fossa (Jolly, 1972, p. 63). The Hopefield remains do not have any appreciable development of fossae. However, considering the large amount of variation in fossa depth among extant baboons (Fig. 7), this small difference is not significant.

Available symphyseal morphology is similar between Hopefield and Olduvai Bed I/ Upper Bed II Theropithecus. One specimen from Olduvai (M14938) has a flat inferior symphyseal surface, a superior symphyseal shelf that "extends posteriorly to the level of the anterior part of the $\mathrm{P}_{4}$ ", and an inferior shelf that extends "to the level of the anterior cusps of the $\mathrm{M}_{1}$ " (Jolly, 1972, p. 63). This description agrees closely with the morphology of 16649 , the adult female specimen from Hopefield. M14938 differs from other East African Theropithecus in that "the anterior part of the symphyseal shelf is rather more steeply sloping" (Jolly, 1972), although no clear differences from the Hopefield specimen are apparent (see Jolly, 1972, Plate 16).

The size difference between Hopefield and Olduvai Bed I/Lower Bed II fossils are illustrated by the larger Hopefield tooth dimensions (see Fig. 5).

In summary, Hopefield and Olduvai Bed I/ Lower Bed II fossil Theropithecus differ in 1) size as reflected in cheek tooth dimensions and 2) relative $P_{3}$ length. Two other differences of the Olduvai specimens, development of the fossa of the mandibular corpus and an anteriorly deepening mandibular corpus, are small and their significance is unclear.

Upper Bed II.. The Theropithecus from Olduvai Upper Bed II do not differ from Hopefield in any significant features. The dentition of mandibular fragments, BKII (juv. female), 1953/117, and M14953 (female), 
"agree with those of Kanjera and Olorgesailie in general structure" (Jolly, 1972 p. 59). BKII also lacks a fossa of the mandibular corpus. A composite description of an Upper Bed II mandible based on two male specimens 067/5603, and OLD/63,3366 (Leakey and Leakey 1973, p. 107) is as follows: 1) "The mandibular corpus is ... slightly deeper below the premolars than below the $\mathrm{M}_{3}$." 2) The fossae of the mandibular corpora "are represented by slight depressions." 3) "On the inferior aspect,... the symphysis extends just posterior to the level of the $\mathrm{P}_{4}$. On the superior aspect, . . . the symphysis extends just posterior to the level of the $\mathrm{P}_{3}$." Mandibular height is $43 \mathrm{~mm}$ anterior to $\mathrm{M}_{3}$ and $46 \mathrm{~mm}$ anterior to $\mathrm{M}_{1}$ for $067 / 5603$ (Leakey and Leakey, 1973, p. 106).

The Hopefield mandibles are similar to Upper Bed II remains in most morphological features including tooth form and symphyseal morphology. Small discrepancies in the fossa of the mandibular corpus (Fig. 9) and the relative depth of the anterior mandibular corpus are not significant.

Size similarity between Hopefield and Olduvai Upper Bed II Theropithecus is sug. gested by the considerable overlap of the ranges of dental measurements (Figs. 5, 6).

Bed IV and lower Ndutu Beds. The Theropithecus mandibles from Olduvai Bed IV and lower Nduto Beds (M14680; OLD/1472,57) are similar to the remains from Upper Bed II and Hopefield. Jolly's (1972, p. 65) description of $\mathrm{P}_{3}$ in these fossils as "exceptionally short and broad, with a very short sectorial face" is supported by the high $\mathrm{P}_{3}$ breadth/ length index (Table 3, Fig. 10). The fossils do not have fossae of the mandibular corpora (Fig. 9) and the lower Ndutu Beds specimen has a symphysis similar to specimens from Kanjera and Olorgesailie (Jolly, 1972). The Bed IV mandible (M14680) exhibits no other unusual features (Jolly, 1972; Leakey and Leakey, 1973).

OLD/1472,57, the type specimen of Simo pithecus jonathoni, has elicited some controversy (Leakey and Whitworth, 1958; Leakey, 1965). This specimen is probably male based on canine cross-sectional areas, which are intermediate between expected male and female values (Jolly, 1972) and based on the large canine root size (Leakey and Leakey, 1973). Conversely, the sectorial blade on $P_{3}$ is quite short, indicating a female. Sex determination is confounded by the extreme wear of the dentition. For purposes of the tables and figures in this paper, OLD/1472,57 is considered a male, so as to conform with the most recent points of view on the sex of this specimen (Jolly, 1972; Leakey and Leakey, 1973; Szalay and Delson, 1979).

Leakey and Leakey (1973) suggest that OLD/1472,57 is unusual in having 1) relatively wide molar teeth and 2) an almost vertical ascending ramus. An index of $\mathrm{M}_{2}$ breadth divided by length shows that this specimen does have relatively wide $\mathrm{M}_{2} \mathrm{~s}$. The index for OLD/1472,57 (.92) is larger than the largest values found among available male Theropithecus at Hopefield (.85), Makapan (.88), Swartkrans (.72), and Olduvai Bed IV (.77). However, the situation is not so clear for indices constructed with $\mathrm{M}_{1}$ or $\mathrm{M}_{3}$ dimensions. For instance, a Makapan specimen (M3081) has a breadth/length index for $M_{1}$ of .90 , which exceeds the value of .83 for OLD/ 1472,57. Larger sample sizes are needed to resolve this problem.

The second difference, the orientation of the ascending ramus in $\mathrm{OLD} / 1472,57$, has been discussed by Jolly (1972, p. 65), who states that the steep vertical ramus is a result of postmortem distortion of the left side of the mandible rather than the real anatomical relationship. The right side has an orientation of the ramus similar to Kanjera specimens.

Theropithecus is slightly smaller at Hopefield than Olduvai Bed IV and lower Ndutu Beds for most dental measurements, although there is some overlap with the largest Hopefield specimen (see Table 2, Fig. 5).

\section{Taxonomy}

The Hopefield Theropithecus mandibular fragments and teeth discussed in this paper further help to elucidate 1) the taxonomic position of the Hopefield form, and 2) the taxonomic diversity of fossil Theropithecus at the Hopefield site itself.

Singer (1962) places all Hopefield fossil baboons in the genus Simopithecus. Jolly (1972) sinks the genus Simopithecus into Theropithecus, subgenus Simopithecus. This latter convention is followed by other workers (Delson, 1975; Eck, 1977; Szalay and Delson, 1979) and is used here despite objections by Maier (1972) and Freedman (1976).

The specific status of Hopefield Theropithecus has been alternately claimed to be $S$. oswaldi (Singer, 1962), T. (S.) oswaldi (Jolly, 1972; Szalay and Delson, 1979), and $S$. darti (Freedman, 1976). The species name T. os- 
waldi is used by Jolly (1972) to denote fossil Theropithecus remains from Middle and Up. per Pleistocene sites throughout Africa. Remains from Olduvai Bed I and Lower Bed II, Swartkrans, and Makapan are placed in $T$. (S.) darti. Likewise, Szalay and Delson (1979) refer Hopefield remains to $T$. oswaldi along with remains from most fossil Theropithecus sites including Swartkrans and the Lower Beds at Olduvai. Szalay and Delson refer the Makapan specimens and currently undescribed remains from Hadar and the lower member of the Koobi Fora formation at East Turkana to Theropithecus darti. Freedman (1976) places the Hopefield remains in $S$. darti along with Theropithecus from Makapan and Swartkrans but groups the East African remains in $S$. oswaldi.

Most of the morphological features on which the above taxonomic assessments are based are reviewed in this paper. Freedman's views are not considered as they are based primarily on geographical rather than morphological criteria. Although different in the taxonomic assessment of a few groups (e.g., Swartkrans and the Lower Beds at Olduvai), Jolly (1972) and Szalay and Delson (1979) base their taxonomic conclusions on similar morphological criteria. They suggest that $T$. oswaldi is a successional species to $T$. darti with a number of advanced morphological features. Such features relevant to the Hopefield remains include 1) reduced fossae of the mandibular corpora; 2 ) reduced $\mathrm{P}_{3}$ length and canine height; 3) flattened upper symphyseal shelf; 4) mandibular corpora of constant depth anteriorly and posteriorly; 5) more specialized cheek teeth; and 6) smaller incisors. Extensive discussion in this paper demonstrate that most of these traits do not reliably separate the alleged primitive forms (Makapan and Olduvai Bed I and Lower Bed II) from the advanced forms (Kanjera, Olorgesailie, Swartkrans, Olduvai Upper Bed II, Bed IV and lower Ndutu Beds, and Hopefield) when variation in the fossil groups and in extant baboon groups is considered. This is especially true for such traits as size of the fossa of the mandibular corpus, slope of the upper symphyseal shelf, and variation in depth of the mandibular corpus. Other traits, such as canine crown height, cheek tooth morphology, and incisor size, are not well documented among the fossils. One of these traits, canine crown height, shows considerable variation in modern baboon groups. Overall size and relative $P_{3}$ length best sep- arate the fossil Theropithecus groups, although these traits do not order the groups on either chronological or geographical grounds. For instance, specimens from Makapan, Swartkrans, Hopefield, and Kanjera have similar proportions for male $\mathrm{P}_{3} \mathrm{~s}$ (Table 3 and Fig. 10) despite differences in provenience. Thus, Theropithecus mandibular morphology supports the view that all forms considered as T. oswaldi or T. darti should be placed in a single fossil species T. oswaldi as suggested by Singer (1962). Szalay and Delson $(1979$, p. 379$)$ also suggest that with further material "a single species might be the best way to recognize this situation taxonomically."

Singer's (1962) designation of the Hopefield material as the subspecies $S$. o. hopefieldensis is maintained by Freedman (1976) and Szalay and Delson (1979). Conversely, Jolly (1972) places the Hopefield specimens in T. $o$. mariae because of similarity in size and other features to Olorgesailie remains. Data presented in this paper indicate that the Hopefield remains differ little from other sites, especially remains from Olorgesailie, Swartkrans, and the Upper Beds at Olduvai, which are similar to the Hopefield remains in size. Thus, the only criteria for maintaining subspecific distinctions between these groups are geographic separation or taxonomic convenience, neither of which are sufficient: Subspecific distinctions should be based on morphological criteria (Mayr, 1970). If geographic separation is the basis for taxonomic separation, a sample can be referred to as that from a particular locality rather than as a formal subspecies. For instance, the Hopefield remains should be designated " $T$. $o s$ waldi from Hopefield" rather than by the formal subspecific nomen, "T. oswaldi hopefieldensis". We conclude that the subspecific name for the Hopefield Theropithecus remains be dropped until distinct morphology can distinguish these specimens from other groups. Likewise, the use of subspecific nomina for all fossil Theropithecus groups should be reconsidered. Comparative mandibular data presented in this paper do not make a compelling case for any subspecific classification in the Theropithecus oswaldi species.

Questions about the number of Theropithecus taxa at Hopefield are raised by Jolly (1972, p. 70 ), who states that "the total range of dental size represented by the sample is considerable... It is questionable whether such a range can be attributed solely to sex- 
ual dimorphism and intrapopulational variability, and the possibility arises that more than one form may be represented, a possibility which can only be tested in the light of further material." Jolly (1972, his Table 4) presents data from Singer (1962) on Hopefield dental dimensions of which only $\mathrm{M}^{1}$ measurements have more than a single observation. Jolly gives ranges for $\mathrm{M}^{1}$ dimensions that are large. For instance, anterior breadth ranges from $9.9 \mathrm{~mm}$ to $14.0 \mathrm{~mm}$ (n $=2$ ). Conversely, Singer (1962, his Table VII) gives only a single measurement for $\mathrm{M}^{1}$ anterior breadth, $14.0 \mathrm{~mm}$. The smaller measurement given by Jolly is identical to the measurement of the Makapan females given in the column adjacent to the Hopefield specimen datum in Table IV of Singer (1962). Likewise, for $\mathrm{M}^{1}$ posterior breadth, Jolly miscopies Singer's (1962) figures, 12.0-12.5 mm, as $9.5-12.5 \mathrm{~mm}$. The lower $9.5 \mathrm{~mm}$ figure is identical to a figure given by Singer (taken from Freedman, 1957) for Makapan females. Thus, the range of variation for Hopefield dental measurements given by Jolly (1972) is a miscopying of Singer's data and is not too large to be accounted for within a single taxon. Data presented in this paper (Table 2, Fig. 5) also show that the range of Hopefield dental measurements is not exceptional compared to ranges of dental measurements for other fossil groups.

Jolly (1972) and Maier (1972) also suggest that the Theropithecus calvaria $(8400 \mathrm{a}, \mathrm{b}, \mathrm{c}, \mathrm{e})$ from Hopefield described by Singer (1962) is small relative to the size of the dentition and mandibular remains from other Hopefield specimens. However, data given by Singer (1962) for glabella-inion length or minimum frontal breadth indicate that this calvaria is similar in size to both a male, F3668, and female, M14936, specimen from Kanjera (Jolly, 1972, his Table 3) and a female, SK.561, from Swartkrans (Freedman, 1957, his Table 16a) while it is larger than two Makapan females, M.3073 and MP.222, (Maier, 1970, his Table II; Freedman, 1976, his Table 2) and smaller than the possibly female Olduvai Bed II specimen, BKII 1957, (Jolly, 1972, his Table 3). On the whole, this small sample of fossil calvaria does not indicate an unusual size for the Hopefield specimen relative to dental measurements from other Hopefield specimens, especially if the Hopefield calvaria is female (as suggested by Singer, 1962) or juvenile. Therefore, the cal- varia size does not suggest multiple taxa at Hopefield.

\section{Ecology}

A survey of the fauna of African Pleistocene localities (Jolly, 1972) reveals that Theropithecus is found primarily at "waterside sites." Jolly (p. 102) concludes: "it seems reasonable to infer that Theropithecus populations living in the lowlands of tropical Africa ... frequented preferentially the alluvial flats surrounding shallow lakes and vleis. Such areas would ... support a rich and dense ground-flora, especially grasses, but, being liable to season flooding, are unlikely to have been wooded or forested." This scenario corresponds with the hypothesized physical conditions at Hopefield during the periods of deposition when the site consisted of a series of vleis, or freshwater lagoons, with natural drainage blocked or slowed by offshore dunes (Singer and Wymer, 1968).

Some parallels exist between the environment of fossil and modern Theropithecus leading to inferences about the diet of the fossil forms (Jolly, 1972). Modern T. gelada live at high altitudes in the montane grasslands and alpine communities of the Ethiopian highlands (Hall, 1966; Starck and Frick, 1958). Studies from several localities reveal T. gelada to be almost exclusively graminivorous, eating grass seeds, dry and fresh grass blades and stems, roots and small bulbs, and a few other plant products (Crook and Aldrich-Blake, 1968; Dunbar, 1977; Dunbar and Dunbar, 1974; Iwamoto, 1975, 1978, 1979; Slatkin, 1975). Similar dietary items would have constituted food products available in open grasslands at Hopefield and probably were an important part of the diet of Hopefield Theropithecus.

Mandibular and dental morphology of Hopefield Theropithecus also suggest a possible graminivorous diet. The cheek teeth of extant and fossil Theropithecus, as discussed in detail by Jolly $(1970,1972)$, share general features such as high crowns, complex ridg. ing, and columnar shape with other graminivorous mammals including bovids, equids, elephantids, and microtin rodents.

The incisor wear pattern of fossil Theropithecus suggests usage similar to that of modern savannah baboons or drills and mandrills. The left $\mathrm{I}^{2}$ from Hopefield (16680) and a specimen from Swartkrans (Freedman, 1957, p. 208) show much wear and lean me- 
sially, as in older Papio and Mandrillus, and are dissimilar from the straight, closely packed incisors of modern Theropithecus. Reports of incisor use in modern savannah baboons include biting pieces from larger objects (Hamilton et al., 1978; Rose, 1977), tearing meat from animal carcasses (Harding, 1973, 1975; Rose, 1977), pulling up rhizomes (Dunbar and Dunbar, 1974) and sedges (Rhine and Westlund, 1978), prying limpets from rocks (Hall, 1961), and removing inedible layers in tamarind preparation (Rhine and Westlund, 1978). By contrast, Dunbar and Dunbar (1974) report that geladas loosen dirt around a root and remove it manually. Likewise, geladas collect seeds by "stripping standing stems between the thumb and index finger" although they also collect seeds by pulling the grass stems through the teeth one at a time (Dunbar, 1977, p. 258). The increased dental wear of the limited sample of fossil incisors suggests that the anterior dentition of the fossil forms was used for a wider variety of tasks than in modern geladas.

The deep mandibular corpus of extant and fossil Theropithecus may reflect an adaptation to prevent fatigue failure of mandibular bone due to repeated bending moments generated on the balancing side corpus during mastication (Hylander, 1979, p. 230). Such bending moments presumably would be more frequent in graminivorous animals due to the relatively greater amount of mastication necessary to break up grasses and seeds than other food items such as fruits. Likewise, the symphysis of Theropithecus is well buttressed, which would better enable it to counter repeated shearing stresses such as those that have been found to be generated at the symphysis during mastication in macaques (Dechow and Carlson, 1983).

\section{ACKNOWLEDGMENTS}

The specimens of extant primates used in this study are housed in the American Museum of Natural History, New York; the British Museum of Natural History, London; The Cleveland Museum of Natural History; the Field Museum of Natural History, Chicago; the Florida State Museum, Gainesville, Florida; the Leiden Museum of Natural History, The Netherlands; the Museum of Comparative Zoology, Cambridge, Massachusetts; the U.S. National Museum of Natural History, Washington, D.C.; the Laboratoire d'Anato- mie Comparée and the Laboratoire de Zoologie of the Museum National D'Histoire Naturelle, Paris; Senckenbergische Anatomie, Frankfurt am Main; Natur-Museum Senckenberg, Frankfurt am Main; Koninklinjk Museum voor Midden Afrika, Tervuren, Belgium; and the Anthropology Department of New York University.

The Hopefield fossils were collected over several years under the direction of one of us (R.S.). Numerous students from the University of Cape Town participated as well as professional field assistants including Peter Saunders and Jeremy Adams, to all of whom our appreciation is expressed.

Research was carried out under several grants: NIH Fellowship DEO5271 (to P. Dechow), and NIH GM-10113, NSF GS-961, and grants from the Wenner-Gren Foundation for Anthropological Research, the Boise Fund of Oxford University, the Lichtenstern Fund, and the Abbott Fund of the University of Chicago (to R. Singer).

Photographic assistance was provided by Ms. Shirley Aumiller, University of Chicago, Mr. Les Siemens, Ms. Clara Franklin, and Medical Photography of the University of Michigan. Some illustrations were drawn by Ms. Nancy Bates.

\section{LITERATURE CITED}

Andrews, CW (1916) Notes on a new baboon (Simopithecus oswaldi, gen. et sp. n.) from the (?) pliocene of British East Africa. Annu. Mag. Nat. Hist. 18:(8th series):410-419.

Arambourg, C (1947) Mission Scientifique de l'Òmo 1932-1933. Tome I, Géologie-Anthropologie. Muséum National D'Histoire Naturelle, Fascicule III, Contribution a L'Étude Géologique et Paléontologique du Bassin du Lac Rudolphie et de la Basse Vallée de L'Òmo.

Arambourg, C (1962) Les faunes mammalogiques du Pléistocène circumméditerranéen. Quaternaria 6:97109.

Butzer, KW (1971) The Lower Omo Basin: Geology, fauna and hominids of plio-pleistocene formations. Naturwissenschaften 58:7-16.

Carney, J, Hill, A, Miller, J, and Walker, A (1971) Late australopithecine from Baringo District, Kenya. Nature 230:509-514

Crook, JH, and Aldrich-Blake, P (1968) Ecological and behavioural contrasts between sympatric ground dwelling primates in Ethiopia. Folia Primatol. 8:192227.

Dechow, PC (1980) Functional Morphology of the Cranofacial Skeleton of Baboons. Ph.D. dissertation, University of Chicago, Chicago.

Dechow, PC (1981) Evaluation of primitive morphological features of Makapansgat Theropithecus. Am. J. Phys. Anthropol. 54:213-214(Abstract).

Dechow, PC, and Carlson, DS (1983) In vivo symphyseal 
bone strain in the macaque mandible. Anat. Rec. 205:44A-45A(Abstract).

Delson, E (1974) Preliminary review of cercopithecid distribution in the Circum Mediterranean region. Mem. Bur. Rech. Geol. Min. (France) 78:131-135.

Delson, E (1975) Evolutionary history of the cercopithecidae. In Szalay, F (ed): Approaches to Primate Paleobiology. Contrib. Primatol. 5:167-217.

Dietrich, WO (1942) Ältestquartare Säugetiere aus der Südlichen Serengeti, Deutsch-Ostafrika. Palaeontographica 93:43-133.

Drennan, MR (1954) Saldanha man and his associations. Am. Anthropol. 56:879-884.

Drennan, MR, and Singer, R (1955) A mandibular frag ment, probably of the Saldanha skull. Nature 175:364.

Dunbar, RIM (1977) Feeding ecology of gelada baboons: A preliminary report. In Clutton-Brock, TH (ed): Primate Ecology. New York: Academic Press, pp. 251273.

Dunbar, RIM, and Dunbar, EP (1974) Ecological relations and niche separation between sympatric terrestrial primates in Ethiopia. Folia Primatol. 21:36-60.

Eck, GG (1976) Cercopithecoidea from Omo group deposits. In Coppens, Y, Howell, FC, Isaac, GL, and Leakey, REF (eds.) Earliest Man and Environments in the Lake Rudolf Basin. Chicago: University of Chicago Press, pp. 332-344.

Eck, GG (1977) Diversity and frequency distribution of Omo group cercopithecoidea. J. Hum. Evol. 6:55-63.

Eck, GG, and Howell, FC (1982) Un primate des forma tions plio-pleistocènes d'Afrique orientale: Theropithecus brumpti (Arambourg), Primates, Cercopithecidae. C.R. Acad. Sci. [D] (Paris) 295(D II):397-400.

Ewer, RF, and Singer, R (1956) Fossil carnivora from Hopefield. Ann. S. Afr. Mus. 42:335-347.

Freedman, L (1957) The fossil cercopithecoidea of South Africa. Ann. Transvaal Mus. 23:121-262.

Freedman, L (1960) Some new cercopithecoid specimens from Makapansgat, South Africa. Palaeontol. Afr. 7:745.

Freedman, L (1976) South African fossil cercopithecoides: a re-assessment including a description of new material from Makapansgat, Sterkfontein and Taung. J. Hum. Evol. 5:297-315.

Freedman, L, and Brain, CK (1977) A re-examination of the cercopithecoid fossils from Swartkrans (Mammalia: Cercopithecidae). Ann. Transvaal Mus. 30:211218.

Geraads, D (1979) La faune des gisements de Melka Kunture (Ethiopie): Artiodactyles, Primates. Abbay (CNRS, Paris) 10:21-50.

Geraads, D (1980) La faune des sites à Home erectus des carrières Thomas (Casablanca, Maroc), Quaternaria 22:65-95.

Hall, KRL (1961) Feeding habits of the chacma baboon. Adv. Sci. 17:559-567.

Hall, KRL (1966) Distribution and adaptations of baboons. Zool. Soc. Lond. Symp. 17:49-73.

Hamilton, W.J, Buskirk, RE, and Buskirk, WH (1978) Omnivory and utilization of food resources by chacma baboons, Papio ursinus. Am. Nat. 112:911-924.

Harding, RSO (1973) Predation by a troop of olive baboons (Papio anubis). Am. J. Phys. Anthropol. 38:587592.

Harding, RSO (1975) Meat-eating and hunting in baboons. In Tuttle, RH (ed): Socioecology and Psychology of Primates. Paris: Mouton, pp. 245-257.

Hay, RL (1976) Geology of the Olduvai Gorge. University of California Press, Berkeley.
Hendey, QB (1974) The Late Cenozoic carnivore of the southeastern Cape Province. Ann. S. Afr. Mus. 63:1369.

Hopwood, AT (1934) New fossil mammals from Olduvai, Tanganyika Territory. Ann. Mag. Nat. Hist. Lond. 14(10th series):546-550.

Hopwood, AT (1936) New and little-known fossil mammals from the Pleistocene of Kenya Colony and Tan ganyika Territory. Ann. Mag. Nat. Hist. $17(10$ th series):636-641.

Hopwood, AT (1939) Appendix B, The mammalian fossils. In O'Brien, TP (ed): The Prehistory of the Uganda Protectorate. Cambridge: University Press, pp. 308 316.

Hooijer, DA, and Singer, R (1960) Fossil rhinoceroses from Hopefield, South Africa. Zool. Med. Museum Leiden 37(8):113-128.

Hooijer, DA, and Singer, R (1961) The fossil hippopotamus from Hopefield, South Africa. Zool. Med. Mus. Leiden 37(10): 157-165.

Hylander, WL (1979) Functional significance of primate mandibular form. J. Morphol. 160:223-240.

Inskeep, RR, and Hendey, QB (1966) An interesting association of bones from the Elandsfontein fossil site. Actas v Congr. Panagr. Prehist. Estudio Cuaternario 2(6):109-124.

Iwamoto, T (1975) Food resource and feed activity, stud ies of the gelada society (III). Contemporary Primatol ogy, 5th Int. Congr. Primatol. Basel: Karger, pp. 475480.

Iwamoto, T (1978) Food availability as a limiting factor on population density of the Japanese monkey and gelada baboon. Chivers and Herbert (eds): Recent Advances in Primatology, Vol. 1. London: Academic Press, pp. 287-303.

Iwamoto, T (1979) Feeding ecology. In Kawai, M (ed): Ecological and sociological studies of gelada baboons. Contrib. Primatol. 16:280-330.

Jolly, CJ (1970) The large African monkeys as an adaptive array. In Napier, JR, and Napier, PH (eds): Old World Monkeys: Evolution, Systematics, and Behavior. New York: Academic Press, pp. 139-174.

Jolly, CJ (1972) The classification and natural history of Theropithecus (Simopithecus, (Andrews, 1916), baboons of the African Plio-Pleistocene. Bull. Br. Mus. Nat. Hist. (Geol.) 22:1.

Kalb, JE, Jolly, CJ, Mebrate, A, Tebedge, S, Smart, C, Oswald, EB, Cramer, D, Whitehead, P, Wood, CB, Conroy, GC, Adefris, T, Sperling, L, and Kana, B (1982a) Fossil mammals and artefacts from the Middle Awash Valley, Ethiopia. Nature 298:25-29.

Kalb, JE, Jolly, CJ, Tebedge, S, Mebrate, A, Smart, C, Oswald, EB, Whitehead, P, Wood, CB, Adefris, T, and Rawn-Schatzinger, V (1982b) Vertebrate faunas from the Awash Group, Middle Awash Valley, Afar, Ethiopia. J. Vertebr. Paleontol. 2:237-258.

Kalb, JE, Wood, CB, Smart, C, Oswald, EB, Mabrete, A, Tebedge, S, and Whitehead, P (1980) Preliminary geology and palaeontology of the Bodo D'Ar hominid site, Afar, Ethiopia. Palaeogeogr. Palaeoclimatol. Palaeoecol. 30:107-120.

Keen, EN, and Singer, R (1956) Further fossil suidae from Hopefield. Ann. S. Afr. Mus. 42:350-360.

Leakey, LSB (1943) Notes on Simopithecus oswaldi Andrews from the type site. J. E. Afr. Nat. Hist. Soc. $17: 39-44$.

Leakey, LSB (1965) Olduvai Gorge, 1951-1961: Fauna and Background. Cambridge: Cambridge University Press. 
Leakey, LSB, and Whitworth, T (1958) Notes on the genus Simopithecus, with a description of a new species from Olduvai. Coryndon Memorial Museum Occasional Papers, 6.

Leakey, MD, Hay, RL, Curtis, GH, Drake, RE, Jackes, MK, and White, TD (1976) Fossil hominids from the Laetolil Beds. Nature 262:460-466.

Leakey, MG (1976) Cercopithecoidea of the East Rudolf succession. In Coppens, Y, Howell, FD, Isaac, GL, and Leakey, REF (eds): Earliest Man and Environments in the Lake Rudolf Basin. Chicago: University of Chicago Press, pp. 345-350.

Leakey, MG, and Leakey, REF (1973) Further evidence of Simopithecus (Mammalia, Primates) from Olduvai and Olorgesailie. In Leakey, LSB, Savage, RJG, and Cornydon, SC (eds); Fossil Vertebrates of Africa 3. New York: Academic Press, pp. 121-138.

Leakey, REF (1970) New hominid remains and early artifacts from Northern Kenya. Nature 226:223-224.

Maier, W (1970) New fossil cercopithecoidea from the Lower Pleistocene cave deposits of the Makapansgat limeworks, South Africa. Palaeont. Afr. 13:69-107.

Maier, W (1972) The first complete skull of Simopithecus darti from Makapansgat, South Africa and its systematic position. J. Hum. Evol. 1:395-405.

Mayr, E (1970) Populations, Species, and Evolution. Cambridge, MA: Harvard University Press.

Patterson, B, Behrensmeyer, AK, and Sill, WD (1970) Geology and fauna of a new Pliocene locality in Northwestern Kenya. Nature 226:918-921.

Rhine, RJ, and Westlund, BJ (1978) The nature of a primary feeding habit in different age-sex classes of yellow baboons (Papio cynocephalus). Folia Primatol. 30:64-79.

Rose, MD (1977) Positional behaviour of olive baboons (Papio anubis) and its relationship to maintenance and social activities. Primates 18:59-116.

Shipman, P, Bosler, W, and Davis, KL (1981) Butchering of giant geladas at an Acheulian site. Curr. Anthropol. 22:257-268.

Simons, EL, and Delson, E (1978) Cercopithecidae and
Parapithecidae, In Maglio, VJ, and Cooke, HBS, (eds): Evolution of African Mammals. Cambridge, MA: Harvard University Press.

Singer, R (1954) The Saldanha skull from Hopefield, South Africa. Am. J. Phys. Anthropol. 12:345-362.

Singer, R (1957) Investigations at the Hopefield Site. In Clark, JD (ed): Proc. Third Pan-Afr. Congr. Prehist. 1955. pp. 175-182.

Singer, R (1962) Simopithecus from Hopefield, South Africa. Bibl. Primatol. 1:43-70.

Singer, R, and Boné, EL (1960) Modern giraffes and fossil giraffids of Africa. Ann. S. Afr. Mus. 45:375-548.

Singer, R, and Crawford, JR (1957) The significance of the archaeological discoveries at Hopefield, South Africa. J. R. Anthropol. Inst. 88:11-19.

Singer, R, and Heltne, PG (1966) Further notes on a bone assemblage from Hopefield, South Africa. Actas v Congr. Panafr. Prehist. Estudio Cuaternario 2(6):261264.

Singer, R, and Inskeep, RR (1961) A complete fossil equid skull from Hopefield, C.P. S. Afr. Archaeol. Bull. 17:23

Singer, R, and Keen, EN (1955) Fossil suiforms from Hopefield. Ann. S. Afr. Mus. 42:169-179.

Singer, R, and Wymer, J (1968) Archaeological investigations at the Saldanha skull site in South Africa. $\mathrm{S}$ Afr. Archaeol. Bull. 25:63-74.

Slatkin, M (1975) A report on the feeding behavior of two East African baboon species. Contemporary Primatology, 5th Int. Congr. Primatol. Basel: Karger, pp. 418-422.

Stark, D, and Frick, H (1958) Beobachtungen an äthiopischen Primaten. Zool. Jb. 86:41-70, 100-119.

Szalay, FS, and Delson, E (1979) Evolutionary History of the Primates. New York: Academic Press.

Taieb, M, Johanson, DC, Coppens, Y, and Aronson, JL (1976) Geological and palaeontological background of Hadar hominid site, Afar, Ethiopia. Nature 260:289293.

Thomas, P (1884) Quelques Formations d'Eau Douce de l'Algerie. Mem. Soc. Geol. France, Ser. 3, Vol. III, Mem. 2. 